Article

\title{
Implications of Hf Isotopes for the Evolution of the Mantle Source of Magmas Associated with the Giant El Teniente Cu-Mo Megabreccia Deposit, Central Chile
}

\author{
Charles R. Stern ${ }^{1, *(\mathbb{D}, \text { Kwan-Nang Pang }}{ }^{2}$, Hao-Yang Lee ${ }^{2}$, M. Alexandra Skewes ${ }^{1}$ and \\ Alejandra Arévalo ${ }^{3}$ \\ 1 Department of Geological Sciences, University of Colorado, Boulder, CO 80309-0399, USA; \\ skewes@colorado.edu \\ 2 Institute of Earth Sciences, Academia Sinica, Taipei City 115, Taiwan; knpang@earth.sinica.edu.tw (K.-N.P.); \\ haoyanglee@earth.sinica.edu.tw (H.-Y.L.) \\ 3 Escuela de Ingeniería, Universidad de O’Higgins, VI Región 2910000, Chile; aarevalot@gmail.com \\ * Correspondence: Charles.Stern@colorado.edu; Tel.: +1-303-492-7170
}

Received: 27 July 2019; Accepted: 10 September 2019; Published: 12 September 2019

\begin{abstract}
We have determined the $\mathrm{Hf}$ isotopic compositions of 12 samples associated with the giant $\mathrm{El}$ Teniente $\mathrm{Cu}$-Mo megabreccia deposit, central Chile. The samples range in age from $\geq 8.9$ to $2.3 \mathrm{Ma}$ and provide information about the temporal evolution of their magmatic sources from the Late Miocene to Pliocene. Together with previously published data, the new analysis indicates a temporal decrease of $10 \varepsilon_{\mathrm{Hf}(\mathrm{t})}$ units, from +11.6 down to +1.6 , in the $12.7 \mathrm{~m}$.y. from 15 to $2.3 \mathrm{Ma}$. These variations imply increasing incorporation of continental crust through time in the magmas that formed these rocks. The fact that the samples include mantle-derived olivine basalts and olivine lamprophyres suggests that these continental components were incorporated into their mantle source, and not by intra-crustal contamination (MASH). We attribute the increase, between the Middle Miocene and Pliocene, of crustal components in the subarc mantle source below El Teniente to be due to increased rates of subduction erosion and transport of crust into the mantle. The deposit formed above a large, long-lived, vertically zoned magma chamber that developed due to compressive deformation and persisted between $\sim 7$ to 4.6 Ma. Progressively more hydrous mantle-derived mafic magmas feed this chamber from below, providing heat, $\mathrm{H}_{2} \mathrm{O}, \mathrm{S}$ and metals, but no unique "fertile" $\mathrm{Cu}$-rich magma was involved in the formation of the deposit. As the volume of these mantle-derived magmas decreased from the Late Miocene into the Pliocene, the chamber crystallized and solidified, producing felsic plutons and large metal-rich magmatic-hydrothermal breccias that emplaced $\mathrm{Cu}$ and $\mathrm{S}$ into the older ( $\geq 8.9 \mathrm{Ma}$ ) mafic host rocks of this megabreccia deposit.
\end{abstract}

Keywords: El Teniente Cu-Mo deposit; Andean magmatism; subduction erosion; mantle source region contamination; Hafnium isotopes

\section{Introduction}

The isotopic compositions $\left({ }^{87} \mathrm{Sr} /{ }^{86} \mathrm{Sr} \geq 0.7050 ; \varepsilon_{\mathrm{Nd}} \leq-2 ; \varepsilon_{\mathrm{Hf}(\mathrm{t})} \leq+2\right)$ of some recently erupted Andean volcanic rocks indicate that they have incorporated continental crust [1-5]. Two different processes for the incorporation of crust into Andean magmas have been proposed (Figure 1). One, MASH (Mixing, Assimilation, Storage and Homogenization), involves intra-crustal assimilation as mantle-derived magmas rise from their source through the crust to the surface [2]. Another, PEELED, involves a mantle source region contaminated by crustal components subducted below the mantle 
wedge and then released into the wedge by either melting or dehydration and volatile transport $[3,4]$. These two different models have very different implications for geochemical cycling associated with subduction zones, and for the growth and evolution of both the continental crust and mantle [5].
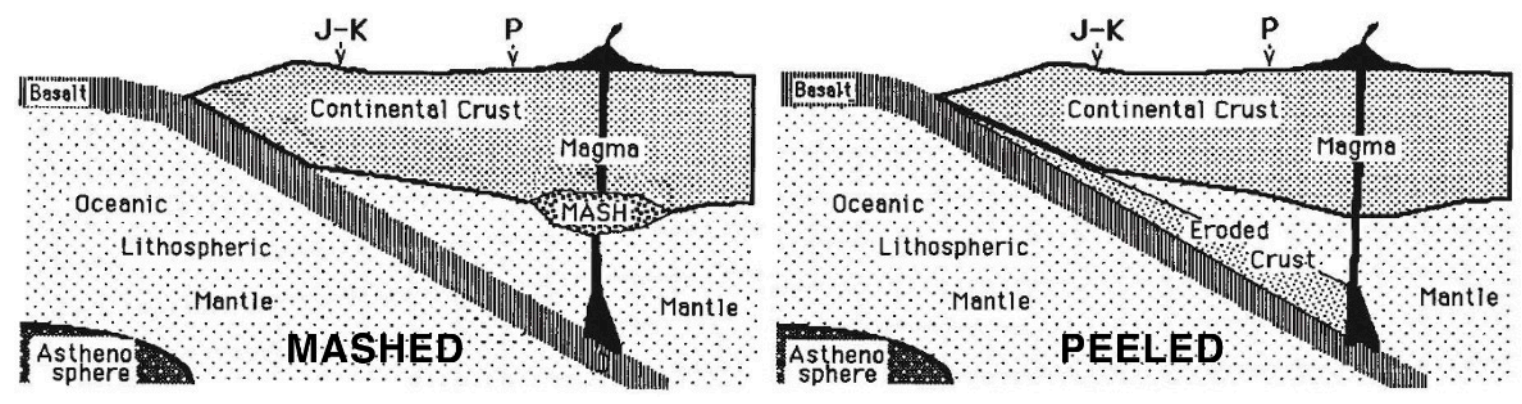

Figure 1. Two alternative explanations, as originally illustrated by Hickey-Vargas in 1991 [1], for the incorporation of continental crust into Andean magmas. MASHED on the left involves Mixing, Assimilation, Storage and Homogenization in a MASH zone located at either the lower crust/mantle boundary or within the crust [2]. PEELED, on the right, involves recycling of subduction eroded crust into the mantle wedge source [3-5]. J-K and P indicate the position of the Jurassic-Cretaceous and Pliocene plutonic belts, respectively, in the Andes of northern Chile. The recently active volcanic arc is $\sim 250 \mathrm{~km}$ east of the Jurassic arc as a result in part of subduction erosion [6]. (Reprinted from Nature, volume 350, Hickey-Vargas, R. Peeled or MASHed?, page 350, Copyright 1991, with permission from Springer Nature.).

The amount of crustal components incorporated into recently erupted Andean volcanic rocks varies along strike from south-to-north, as do various geologic and tectonic features such as crustal thickness and age, subduction angle, trench depth and sediment fill, and the localized presence of buoyant features such as oceanic seamount chains and spreading ridges being subducted below the South American continental margin (Figure 2; [4]). For instance, in the Central Volcanic Zone (CVZ) of northern Chile, the crust is much thicker $(\geq 70 \mathrm{~km})$ than below the central part of the Southern Volcanic Zone ( $\leq 35 \mathrm{~km}$; CSVZ; Figure 2) and the isotopic compositions of the recently erupted volcanic rocks suggests more crustal components have been incorporated in CVZ than CSVZ magmas [3-5]. This could reflect greater amounts of crustal assimilation by mantle-derived magmas as they rose through the thicker CVZ crust, but in this same region, the trench is devoid of sediment due to the arid conditions in northern Chile, and compared to the CSVZ, much more significant amounts of subduction erosion, at rates estimated to be $50-70 \mathrm{~km}^{3} / \mathrm{km} / \mathrm{m}$.y. since 150 Ma (Figure 2; [5]), have truncated the continental margin [6] and caused the arc to migrate eastward $\sim 250 \mathrm{~km}$ since the Jurassic (Figure 1). The subduction of tectonically eroded crust has been invoked not only to explain the crustal components in CVZ magmas [3-5,7,8], but also the uplift and crustal thickening observed in this part of the Andes [9].

In the same way, at the northern end of the Andean SVZ (NSVZ; Figures 2 and 3), where the MASH model was first presented [2], the crust thickens to $\geq 60 \mathrm{~km}$ compared to $\leq 35 \mathrm{~km}$ below the $\mathrm{CSVZ}$, and the isotopic compositions of recently erupted volcanic rocks indicate that they contain greater amount of crustal components [3-5,10,11]. However, the subduction of the Juan Fernández Ridge has caused the subduction angle to flatten, increasing the rate of subduction erosion west of the NSVZ to between 115 and $230 \mathrm{~km}^{3} / \mathrm{km} / \mathrm{m}$.y. over the last $10 \mathrm{~m} . \mathrm{y}$., during which time the active volcanic arc between $33-34^{\circ} \mathrm{S}$ migrated $\sim 50 \mathrm{~km}$ to the east (Figure 3). Stern [3-5] therefore proposed that crustal components were preferentially incorporated in NSVZ compared to CSVZ magmas by increased rates of subduction erosion and mantle source region contamination by subducted components, and not by intra-crustal MASH processes. 


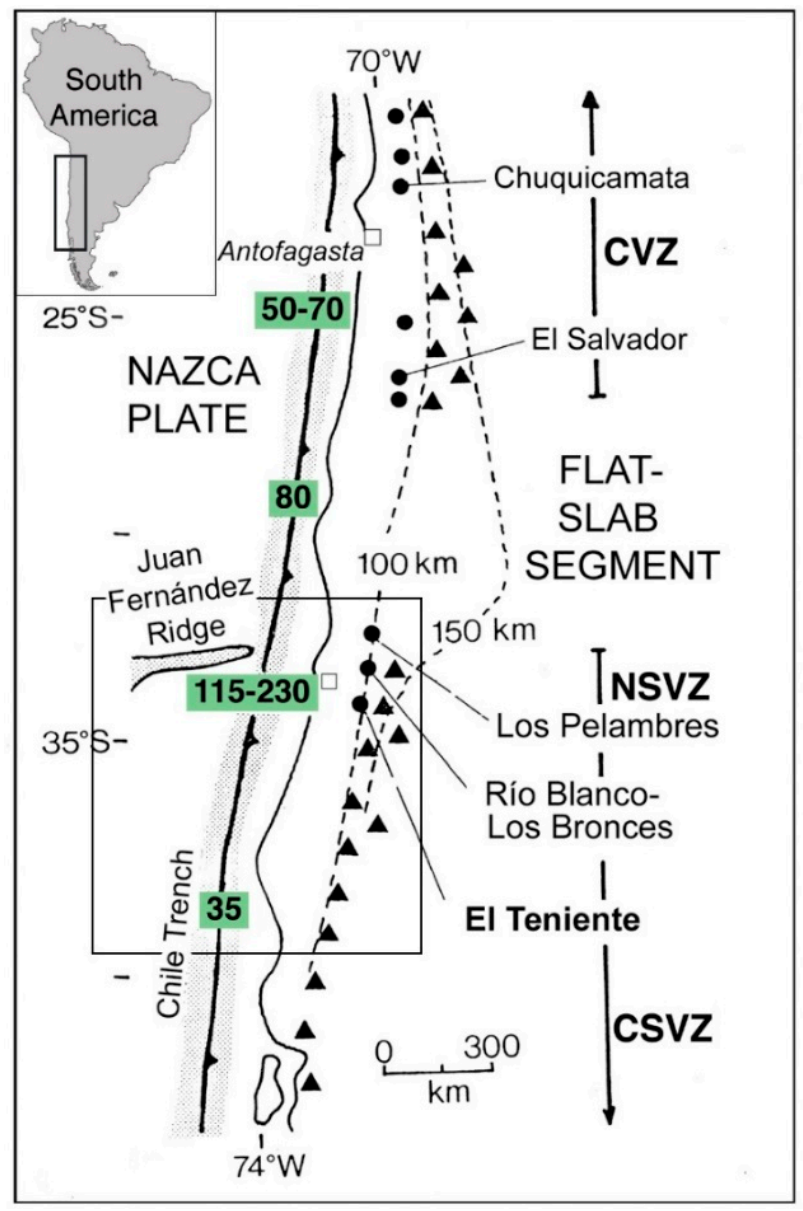

Figure 2. Location map of El Teniente, the two other giant Late Miocene Cu-Mo deposits, Los Pelambres and Río Blanco-Los Bronces, in the Andes of central Chile, and some of the other giant Late Eocene and Early Oligocene Cu-Mo deposits in northern Chile west of the Andean Central Volcanic Zone $(\mathrm{CVZ})$. The area of the figure is indicated by the box in the inset, and the box in the figure shows the region illustrated in Figure 3. The figure also shows tectonic features such as the Chile Trench, which is the boundary between the Nazca and South American plates, and the depth in kilometers (100 and $150 \mathrm{~km}$ dashed lines) to the Benioff Zone below South America. The locus of subduction of the Juan Fernández Ridge occurs at the boundary between the Andean Flat-Slab segment, below which the subduction angle is very low as indicated by the depths to the upper boundary of the subducted slab, and the northern and central parts of the Andean Southern Volcanic Zone (NSVZ and CSVZ) of active volcanoes, below which subduction angle is steeper. The numbers in the green boxes are the estimated rates of subduction erosion in $\mathrm{km}^{3} / \mathrm{km} / \mathrm{m}$.y. in each region [5]. Subduction erosion rates are higher in northern compared to south-central Chile because of the arid conditions in the north, resulting in a trench devoid of sediment, and humid conditions in the south, resulting in a trench filled with sediment $[4,5,9]$. Rates are highest just south of the locus of subduction of the Juan Fernández Ridge due to the effects of the subduction of this buoyant feature [5,26,27]. (Reprinted from Geology, volume 22, Skewes, M.A. and Stern, C.R. Tectonic trigger for the formation of late Miocene Cu-rich breccia pipes in the Andes of central Chile, page 552, Copyright 1994, with fair use permission from the Geologic Society of America.).

Temporal variations in the isotopic compositions of Andean igneous rocks also are not unambiguously related to either changes in crustal thickness or rates of subduction erosion. Below the NSVZ, in the region where the El Teniente deposit formed in the Late Miocene (Figures 2 and 3), the crust has thickened and been uplifted since the Middle Miocene [12-20], and Sr, $\mathrm{Nd}$ and $\mathrm{Pb}$ isotopic data indicate increased proportions of continental crust in the igneous rocks 
emplaced through time (Figures 4 and 5; [10,21-24]). However, as described above, the southward migration of the locus of subduction of the Juan Fernández Ridge has also caused, during this same time period, flattening of the angle of subduction, $>50 \mathrm{~km}$ of eastward migration of the volcanic arc, and increased rates of subduction erosion (Figure 3; [3-5,10,25-27]).

In summary, the spatial and temporal variations in geologic factors such as crustal thickness and rates of subduction erosion rates do not unambiguously favor MASH versus source region contamination in producing the spatial and temporal isotopic variations that indicate increased incorporation of continental crust in some Andean magmas. An alternative approach to distinguish these two processes is geochemical modelling focused specifically on mafic olivine-bearing basaltic rocks clearly derived from the mantle, without significant evidence for or possibility of intra-crustal contamination. For instance, to produce the northward increase of ${ }^{87} \mathrm{Sr} /{ }^{86} \mathrm{Sr}$ from 0.7039 to 0.7050 and decrease in $\varepsilon_{\mathrm{Nd}}$ from $>+5$ to $<-1$ observed in the olivine basalts erupted from CSVZ compared to NSVZ volcanoes (Figures 3-5), would require intra-crustal assimilation (MASH) of $>40$ wt. \% of Andean crust (Figure $4 ;[3,10,21,22]$ ) because of the relative high $\mathrm{Sr} \geq 50 \mathrm{ppm}$ and $\mathrm{Nd} \geq 9 \mathrm{ppm}$ of Andean basalts. For NSVZ olivine basalts with $\sim 50 \mathrm{wt} . \% \mathrm{SiO}_{2}$, but with no macro or microscopic evidence of crustal xenoliths or xenocrysts, this is considered to be an unacceptably large amount of crustal assimilation, as it would increase $\mathrm{SiO}_{2}$ to $\sim 60 \mathrm{wt}$. \%. In contrast, because of the relatively low $\mathrm{Sr}=36 \mathrm{ppm}$ and $\mathrm{Nd}=1.8 \mathrm{ppm}$ of Andean subarc mantle, these variations could be produced by incorporation in the mantle source region of only $5 \mathrm{wt}$. \% more subducted crust and sediment below the NSVZ (Figure 4), where current subduction erosion rates are estimated as between 115 and $230 \mathrm{~km} 3 / \mathrm{km} / \mathrm{m}$.y. (Figure 2), than the $1 \mathrm{wt}$. \% estimated to have been incorporated in the mantle below the CSVZ, where subduction erosion rates are estimated as only $\sim 35 \mathrm{~km}^{3} / \mathrm{km} / \mathrm{m}$.y. (Figure 2).

Similar temporal isotopic changes to those observed between recently erupted CSVZ and NSVZ basalts occurred between the Miocene and Pliocene in igneous rocks associated with the El Teniente Cu-Mo deposit (Figures 3-5; [21-23]). As a contribution to the understanding of Andean magmagenesis and its relation to the formation of the giant El Teniente ore deposit, we have determined the Hf isotopes of igneous rocks ranging in age from $\geq 8.9$ to $2.3 \mathrm{Ma}$ from the area of the deposit. These samples (Table 1) include an olivine basalts (8.9 Ma), an olivine lamprophyre (3.1 Ma), and an olivine-bearing basaltic andesites (2.3 Ma), as well as other mafic and felsic plutons associated with the deposit. The data obtained provide information about the temporal evolution of their magmatic sources from the Late Miocene to Pliocene, and constrain the relative role of MASH and mantle source region contamination processes in the generation of Andean magmas. 


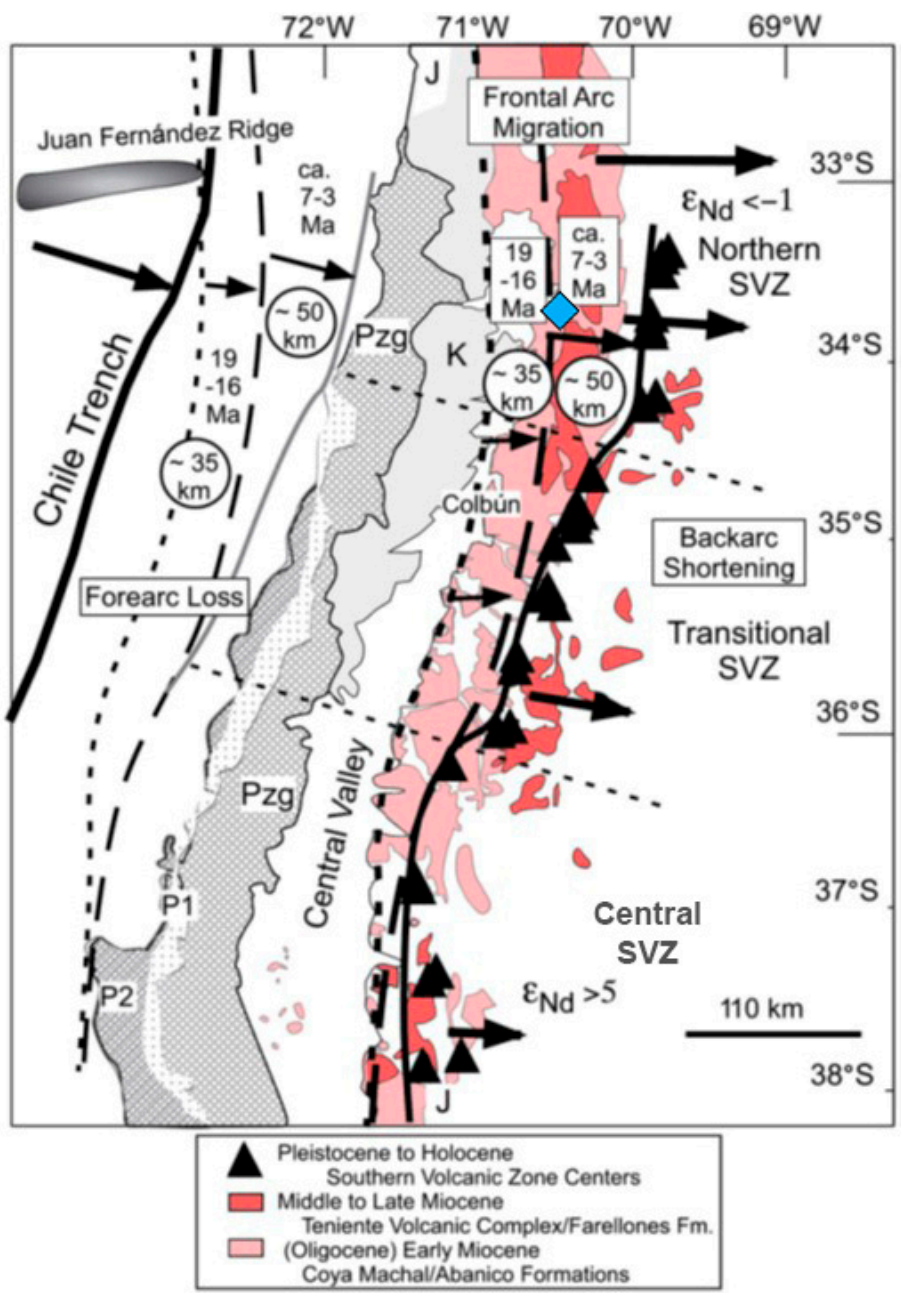

Figure 3. Regional map of central Chile between $\sim 32^{\circ} \mathrm{S}$ and $38^{\circ} \mathrm{S}$, with lines showing correlations of early Miocene to Holocene arc fronts on land and inferred position of corresponding coastlines offshore [10]. Arrows show relative amounts of frontal-arc migration, forearc loss, and backarc shortening. Northwest-southeast trending dashed lines show offsets in the modern volcanic front that separate the Southern Volcanic Zone (SVZ) into the northern, transitional, and central segments [4]. In the active arc region, lines connect outcrop patterns marking early Miocene (pink), middle to late Miocene (red), and the Pleistocene to Holocene volcanic centers of the SVZ (triangles) magmatic fronts. Arrows between the lines indicate inferred distance (given in circles) of frontal-arc migration from 19 to $16 \mathrm{Ma}$ and from 7 to $3 \mathrm{Ma}$. In the forearc, lines between the trench and the coast show inferred early Miocene (short dashed) and middle to late Miocene (long dashed) coastlines under the assumption that the distance of frontal-arc migration equals the width of missing coast. Arrows between the lines in this region indicate distance (shown in circles) of inferred loss by subduction erosion from ca. 19 to 16 Ma. and 7 to $3 \mathrm{Ma}$. In the backarc, the length and position of arrows show the location and proportional amounts of crustal shortening over the past 20 m.y. inferred from structural profiles. Also shown are other outcrop patterns that have long been used as evidence for forearc subduction erosion along this margin [6]. The first is the northward narrowing and disappearance of the Paleozoic high pressure (P1) and low pressure (P2) paired metamorphic and granitoid (Pzg) belts along the coast. The second is the presence of Jurassic arc rocks (marked by J) along the coast north of $33^{\circ} \mathrm{S}$, but inland near the SVZ at $\sim 38^{\circ} \mathrm{S}$. K indicates Cretaceous magmatic rocks. $\varepsilon_{\mathrm{Nd}}$ is +5 for active $\mathrm{SVZ}$ volcanoes south of $36^{\circ} \mathrm{S}$, and $\leq-1$ for those in the northern SVZ north of $34^{\circ} \mathrm{S}$, as a result of increased mantle source region contamination by subducted crust due to the northward increase in the rate of subduction erosion associated with the subduction of the Juan Fernández Ridge at $33^{\circ} \mathrm{S}$ [3-5]. El Teniente occurs at the blue diamond. (Reprinted from Geologic Society of American Bulletin, volume 117, Kay, S.M. et al., Episodic arc magmatism, crustal thickening, subduction erosion, and magmatism in the south-central Andes, page 83, Copyright 2005, with fair use permission from the Geologic Society of America.). 


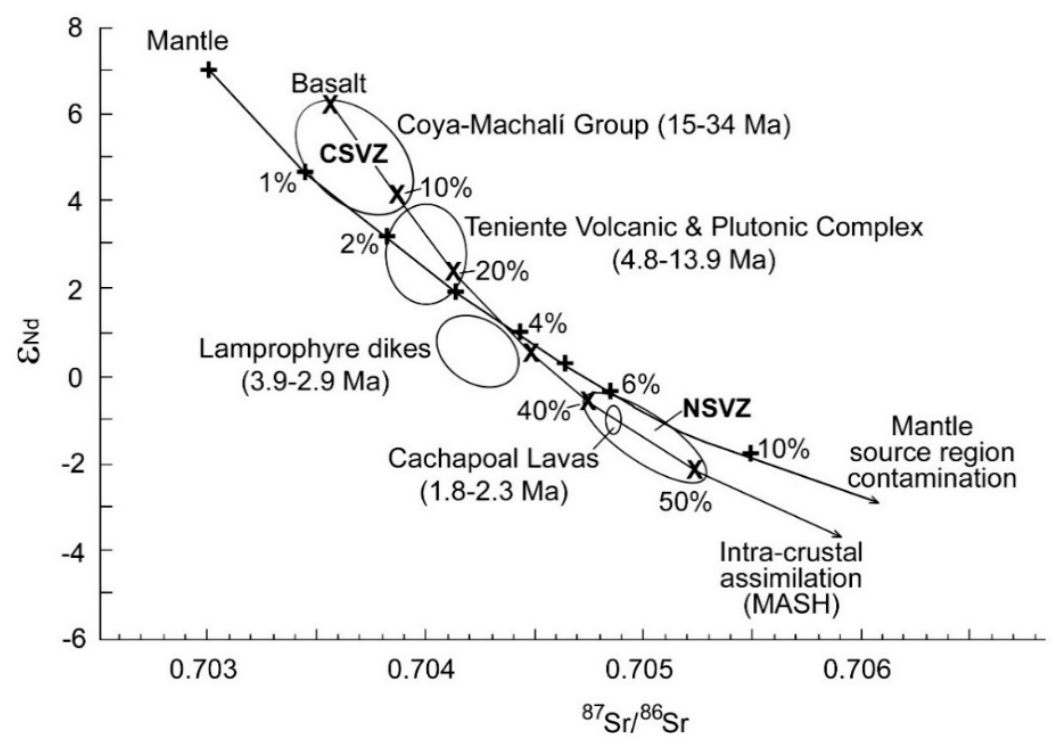

Figure 4. Sr versus $\mathrm{Nd}$ isotopic values of the various groups of igneous rocks of different ages in a transect across the Andes at the latitude of El Teniente (34 ${ }^{\circ}$; $\left.[10,14,17,21-24]\right)$. The figure illustrates both a source region contamination model of primitive mantle $\left(+{ }^{\prime} \mathrm{s}, \mathrm{Sr}=36 \mathrm{ppm}\right.$ with ${ }^{8} 7 \mathrm{Sr} /{ }^{86} \mathrm{Sr}=0.703$ and $\mathrm{Nd}=1.8 \mathrm{ppm}$ with $\varepsilon_{\mathrm{Nd}}=+7$; [21]) mixed with various proportion of subducted crust and sediment $\left(\mathrm{Sr}=380 \mathrm{ppm}\right.$ with ${ }^{87} \mathrm{Sr} /{ }^{86} \mathrm{Sr}=0.70763$ and $\mathrm{Nd}=42.3 \mathrm{ppm}$ with $\left.\varepsilon_{\mathrm{Nd}}=-5.1\right)$, and also a MASH model for a Coya-Machalí basalt $\left(x^{\prime} \mathrm{s}, \mathrm{Sr}=450 \mathrm{ppm}\right.$ with ${ }^{87} \mathrm{Sr} /{ }^{86} \mathrm{Sr}=0.7035$ and $\mathrm{Nd}=9$ ppm with $\varepsilon_{\mathrm{Nd}}=+6$ ) assimilating various proportion of Paleozoic-Triassic Andean granite basement $\left(\mathrm{Sr}=350 \mathrm{ppm}\right.$ with ${ }^{87} \mathrm{Sr} /{ }^{86} \mathrm{Sr}=0.7075$ and $\mathrm{Nd}=20 \mathrm{ppm}$ with $\varepsilon_{\mathrm{Nd}}=-6$; [10]) Both models reproduce the isotopic compositions of the progressively younger rocks in the transect, but the latter model requires assimilation of unacceptably high proportions of granite crust and is inconsistent with generation of primitive low $\mathrm{SiO}_{2}$ olivine-bearing mafic rocks in each age group (Figure 5), as well as the progressively higher Sr content of the sequentially younger rocks, which is due instead to decreasing degrees of partial mantle melting [3-5,10] associated with decreasing volume of magmas erupted through time at this latitude in the Andes. (Reprinted from Geologic Society of American Bulletin, volume 117, Kay, S.M. et al., Episodic arc magmatism, crustal thickening, subduction erosion, and magmatism in the south-central Andes, page 78, Copyright 2005, with fair use permission from the Geologic Society of America.). 


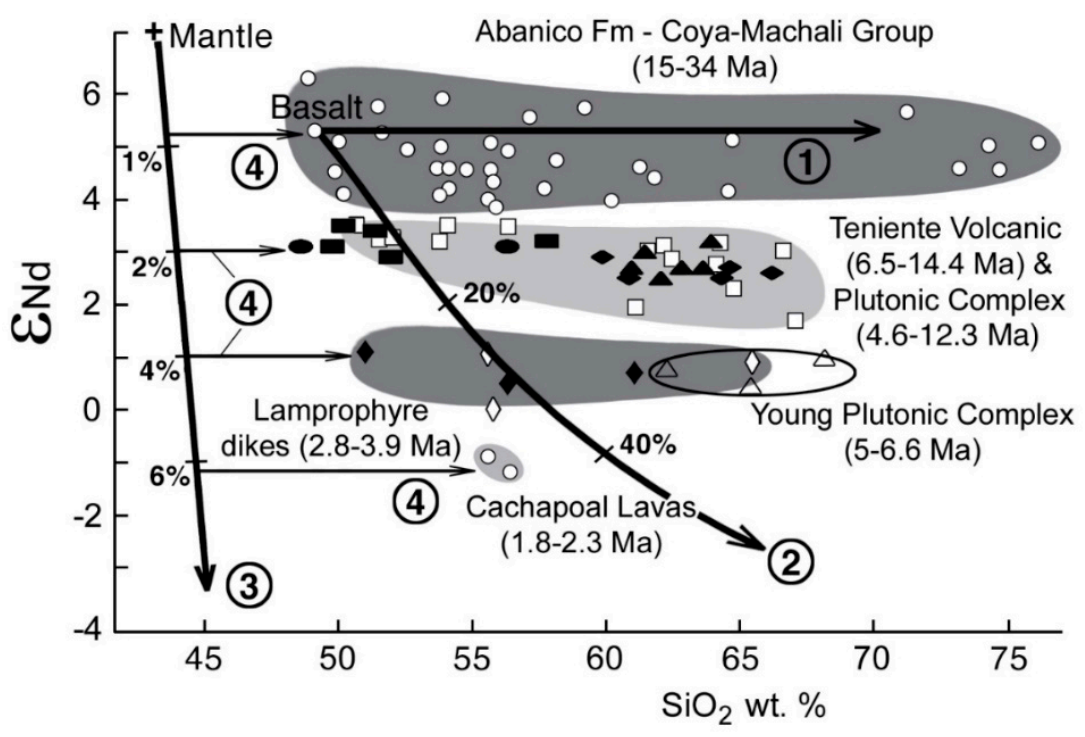

Figure 5. Published values of $\varepsilon_{\mathrm{Nd}} \mathrm{vs} \mathrm{SiO}_{2}$ (wt. \%) for igneous rocks of different ages from the transect across the Andes at the latitude of El Teniente ( $34^{\circ} \mathrm{S}$; open symbols including the Abanico Formation (o), Teniente Volcanic and Plutonic Complexes ( $\square$ ), Young Plutonic Complex $(\Delta)$ and lamprophyres $(\diamond) ;[10,14,17,21-24])$, compared with values for samples of the host-rocks in the deposit

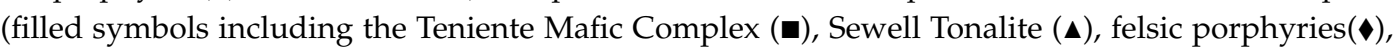
and Porphyry A granitoid (๑); [23]). Three curves illustrate the progressive changes in $\mathrm{SiO}_{2}$ and $\varepsilon_{\mathrm{Nd}}$ for (1) crystal-liquid fractionation without assimilation, (2) intra-crustal assimilation combined with crystal-liquid fractionation (MASH), and (3) mantle source region contamination. Crystal-liquid fractionation increases $\mathrm{SiO}_{2}$ without changing isotopic composition. MASH increases $\mathrm{SiO}_{2}$ as $\varepsilon_{\mathrm{Nd}}$ decreases. Source region contamination decreases $\varepsilon_{\mathrm{Nd}}$ in the mantle, but mantle partial melting (curves (4)) for the modified mantle still produces mafic olivine-bearing basalts and lamprophyres. Tic marks along each curve indicate the same amount of crustal contamination as in the MASH and source region contamination models illustrated in Figure 4. Although the youngest felsic plutons in the deposit are the same age (4.6 to $7.1 \mathrm{Ma}$ ) as rocks from the regionally defined Young Plutonic Complex of small barren plutons outside the deposit (5 to 6.6 Ma; [10]), they are isotopically similar to the older host-rocks of the deposit as well as to the Teniente Volcanic and Plutonic Complex rocks. This is due to the fact that they formed above a large magma chamber within which mantle-derived magmas were mixed, stored and homogenized (but without crustal assimilation), so that the temporal isotopic changes in these mantle-derived magmas through time are not observed in the progressively younger felsic plutons within the deposit as a result of the large volume of the magma chamber into which these mantle-derived magmas mixed. In contrast, the small barren plutons of the Young Plutonic Complex outside the deposit do reflect these temporal changes in isotopic composition because they do not form above such a large magma chamber. (Reprinted from Geologic Society of American Bulletin, volume 117, Kay, S.M. et al., Episodic arc magmatism, crustal thickening, subduction erosion, and magmatism in the south-central Andes, page 80, Copyright 2005, with fair use permission from the Geologic Society of America.). 
Table 1. Samples analyzed. Rock types, $\mathrm{SiO}_{2},{ }^{87} \mathrm{Sr} /{ }^{86} \mathrm{Sr},{ }^{143} \mathrm{Nd} /{ }^{144} \mathrm{Nd}$, and $\varepsilon_{\mathrm{Nd}}$ from [21-23]. $\varepsilon_{\mathrm{Hf}(\mathrm{t})}$ from [28].

\begin{tabular}{|c|c|c|c|c|c|c|c|}
\hline Sample \# & Rock Type & Age Ma & $\mathrm{SiO}_{2}$ wt. $\%$ & ${ }^{87} \mathrm{Sr} /{ }^{86} \mathrm{Sr}$ & ${ }^{143} \mathrm{Nd} /{ }^{144} \mathrm{Nd}$ & $\varepsilon_{\mathrm{Nd}}$ & $\varepsilon_{\mathrm{Hf}(\mathrm{t})}$ \\
\hline \multicolumn{8}{|c|}{ Late Miocene ( $\geq 8.9$ Ma) Mafic Host Rocks } \\
\hline EX-2004-04 & ol basalt & 8.9 & 51.9 & 0.70405 & 0.512782 & 2.9 & \\
\hline $1411-1630$ & gabbro & $\geq 8.9$ & 51.1 & 0.70396 & 0.512818 & 3.5 & \\
\hline $540-2082$ & basalt & $\geq 8.9$ & 51.3 & 0.70404 & 0.512813 & 3.4 & \\
\hline QT-4 & basalt & $\geq 8.9$ & 49.7 & 0.70421 & 0.512798 & 3.1 & \\
\hline \multicolumn{8}{|c|}{ Late Miocene to Early Pliocene (7.1 to 4.8 Ma) Felsic Plutonic Rocks } \\
\hline Ttc5 & Sewell tonalite & 7.1 & 63.7 & 0.70386 & 0.512770 & 2.7 & 7.9 \\
\hline $1473-970$ & Porphyry A & 5.7 & 48.5 & 0.70409 & 0.512799 & 3.1 & \\
\hline $1446-266$ & Porphyry A & 5.7 & 56.3 & 0.70406 & 0.512795 & 3.1 & 7.7 \\
\hline $1300-403$ & Teniente dacite & 5.3 & 66.3 & 0.70402 & 0.512762 & 2.6 & 7.2 \\
\hline $1394-92$ & latite dike & 4.8 & 60.9 & 0.70405 & 0.512785 & 2.5 & 6.9 \\
\hline \multicolumn{8}{|c|}{ Pliocene (3.8 to 2.3) Lamprophyres and Basaltic Andesites } \\
\hline Ttc1 & $\begin{array}{c}\text { hbl } \\
\text { lamprophyre }\end{array}$ & 3.8 & 56.3 & 0.70425 & 0.512660 & 0.7 & \\
\hline AS-2003-1 & ol lamprophyre & 3.1 & 51.3 & 0.70425 & 0.512700 & 1.2 & \\
\hline PVF1 & $\begin{array}{l}\text { ol basaltic } \\
\text { andesite }\end{array}$ & 2.3 & 55.6 & 0.70485 & 0.512580 & -1.1 & \\
\hline
\end{tabular}

\section{Geologic Background}

\subsection{El Teniente Cu-Mo Deposit}

The giant El Teniente Cu-Mo deposit, located in central Chile ( $34^{\circ} 05^{\prime} \mathrm{S}, 70^{\circ} 21^{\prime} \mathrm{W}$; Figures 2 and 3) is one of the largest such deposits in the world [28-38]. It is the southernmost in a belt of three giant Late Miocene Cu-Mo deposits which also includes Los Pelambres and Río Blanco-Los Bronces [39,40]. El Teniente has been described as a porphyry deposit formed around the central Teniente Dacite Porphyry dike (Figure 6; [31]), or alternatively as a magmatic-hydrothermal breccia deposit formed either in association with the intrusion of dacite to diorite dikes [37] or by the generation of multiple large mineralized breccias, including the central Braden breccia pipe, by exsolution of high-temperature mineral-rich magmatic-hydrothermal fluids from the roof of an underlying large, long-lived and vertically stratified magma chamber recharged from below by mantle-derived magmas [23,33,34,38]. The two other Miocene deposits in this belt are also characterized by the presence of multiple large mineralized magmatic-hydrothermal breccias [38-42].

$\mathrm{Pb}, \mathrm{S}, \mathrm{O}$ and $\mathrm{H}$ isotopic studies of the igneous rocks and ore minerals in the deposit indicate that El Teniente is clearly an orthomagmatic deposit, with $\mathrm{Cu}$, Mo and $\mathrm{S}$ being derived from the associated igneous rocks [33,34,39,43-45]. Igneous rocks spatially related with the deposit range in age from mid Tertiary to Pliocene. Over this time period, the volume of magmatic rocks decreased progressively $[22,23,38,39]$, and in the Pliocene the locus of Andean arc magmatism at the latitude of El Teniente ( $34^{\circ} \mathrm{S}$ ), near the current northern end of the Andean Southern Volcanic Zone (NSVZ; Figures 2 and 3), migrated $\sim 50 \mathrm{~km}$ to the east as the subduction angle flattened [25]. This, we suggest, was due to the southward migration of the locus of subduction of the Juan Fernández Ridge [21,25-27,38,39].

The igneous rock in the vicinity of El Teniente include continental volcanic rocks, up to $3300 \mathrm{~m}$ thick, of the Oligocene to Early Miocene ( $\geq 15 \mathrm{Ma}$ ) Coya-Machali or Abanico Formation (Figure 3; [15,46,47]), erupted above thin $(<30 \mathrm{~km})$ crust, or in a transtensional intra-arc basin [48]. These formed by relatively high degrees of partial melting of subarc mantle modified to a small degree by the influx from below of slab-derived components (Figure $5 ;[10,17,46])$. This is indicated by their low La/Yb ratios (2 to 6), as well as their low initial ${ }^{87} \mathrm{Sr} /{ }^{86} \mathrm{Sr}(0.7033-0.7039)$ and high $\varepsilon_{\mathrm{Nd}}(+6.5$ to +4 ; Figures 4 and 5). Although the Coya-Machali Formation volcanic rocks do not crop out either within or in the immediate 
vicinity of the El Teniente deposit (Figures 3 and 6), these rocks occur both to the west and the east of the deposit, and they almost certainly also occur at depth below the deposit.

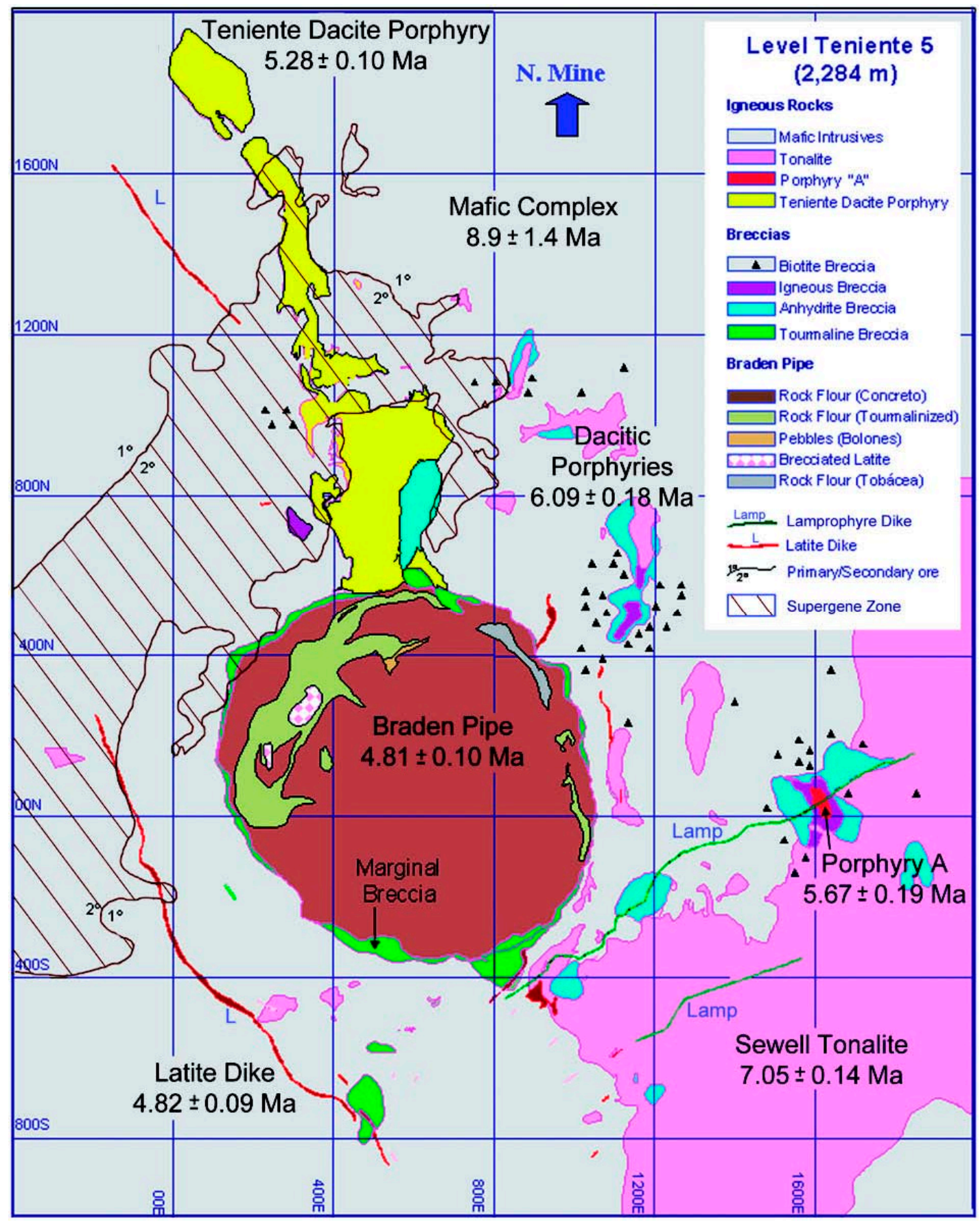

Figure 6. Geological map of level Teniente 5 (2284 $\mathrm{m}$ above sea level) in the mine [33,34]. The Dacitic Porphyries north of the Sewell Tonalite, are mapped as a distal portion of this pluton, although they are younger [35] and have an independent origin [37]. The spatial extent of biotite breccias is projected onto this level from where they have been mapped between levels Teniente 4 and 8 . (Reprinted from Journal of Petrography, volume 52, Stern, C.R. et al., Magmatic evolution of the giant El Teniente Cu-Mo deposit, central Chile, page 1594, Copyright 2011, with permission from Oxford University Press).

Extrusive rocks of the Miocene Farellones Formation, locally referred to as the Teniente Volcanic Complex [10], are the oldest rocks exposed in the immediate area surrounding the deposit (Figure 3). 
The Farellones Formation, a sequence of $>2500 \mathrm{~m}$ of lavas, volcanoclastic rocks, dikes, sills and stocks of basaltic to rhyolitic composition, was erupted after an Early Miocene (19-16 Ma episode of crustal deformation, thickening and uplift $[10,14]$. The Teniente Volcanic Complex near the deposit has been correlated with the upper part of this formation and dated between 14.4 and 6.5 Ma [10,32]. No extrusive rocks with ages less than $6.5 \mathrm{Ma}$ have been found within the El Teniente deposit.

The Teniente Volcanic Complex consists of tholeiitic to calc-alkaline extrusive rocks, which plot in the medium to high-K group of convergent plate boundary arc magmas [10]. Mafic rocks of the Teniente Volcanic Complex generally have higher La/Yb (4 to 9) compared with rocks of the older Coya-Machali Formation, and mafic, intermediate and silicic rocks also have higher initial ${ }^{87} \mathrm{Sr} /{ }^{86} \mathrm{Sr}$ (0.7039-0.7041; Figure 4) and lower initial $\varepsilon_{\mathrm{Nd}}(+2.7$ to +3.6 ; Figures 4 and 5). These differences are interpreted to represent a change from magma genesis below relatively thin continental crust during the mid-Tertiary, when the Coya-Machali Formation was generated, to conditions of thickened continental crust when the Teniente Volcanic Complex formed in the Middle to Late Miocene.

The extrusive rocks of the Teniente Volcanic Complex were intruded between $~ 8.9$ and $4.6 \mathrm{Ma}$, during a Late Miocene episode of further crustal deformation, thickening and uplift, [10,14,32,35,48], by gabbro, diabase, diorite, tonalite, latite, and dacite porphyry plutons of the Teniente Plutonic Complex. Within the immediate area of the deposit (Figure 6) these include (1) the $>50 \mathrm{~km}^{3}$ Teniente Mafic Complex $(8.9 \pm 2.4 \mathrm{Ma})$ of mafic intrusives with the form of a laccolith $2000 \mathrm{~m}$ thick in the center of the deposit; (2) the equigranular holocrystalline Sewell Tonalite complex (7.05 $\pm 0.14 \mathrm{Ma})$, with an estimated volume of $\sim 30 \mathrm{~km}^{3}$ [23]; and (3) a series of much smaller volume ( $<1 \mathrm{~km}$ each) dacite and diorite porphyries $(6.09 \pm 0.18 \mathrm{Ma})$, the unusual $\mathrm{Cu}$ - and S-rich anhydrite-bearing Porphyry A stock (5.67 $\pm 0.19 \mathrm{Ma}$; [49]), the Teniente Dacite Porphyry dike (5.28 $\pm 0.10 \mathrm{Ma}$ ), a few latite dikes $(4.82 \pm 0.09 \mathrm{Ma})$, and finally a small dacite porphyry $(4.58 \pm 0.10 \mathrm{Ma})$. These intrusive rocks have isotopic compositions similar to Teniente Volcanic Complex extrusives (Figures 4 and 5).

Multiple Cu-mineralized magmatic-hydrothermal breccia pipes were emplaced into these plutonic rocks during the same time period as the felsic porphyry intrusions, between at least 6.3 and $4.4 \mathrm{Ma}$ (Figure 6). Post-mineralization phases include high-MgO ( $\geq 7.50 \mathrm{wt}$ \% \%) olivine (Fo88) and hornblende lamprophyres (3.8 to 2.9 Ma; [10,22,32,35]) and olivine (Fo64) basaltic andesite (MgO $\geq 4.5$ wt. \%) lavas in the valley of the Cachapoal river just west of the El Teniente deposit (2.3 Ma; [21]). After this, the locus of Andean arc magmatism migrated eastwards $\sim 50 \mathrm{~km}$ (Figure 3).

\subsection{Previous Hf Isotopic Studies}

Hf isotopes have previously been determined in zircons from felsic plutons both within [28] and in the vicinity [50] of the El Teniente deposit (Figure 7). The Hf isotopic composition of zircons in six samples of felsic plutons within the deposit, that range in age from 7.1 to 4.8 Ma, have overall high initial average of $\varepsilon_{\mathrm{Hf}(\mathrm{t})}=+7.4 \pm 1.2$ and range from +6 to +10 (Table 1 ), which rules out significant crustal contamination [28]. There was little change in these compositions during this time, but the older four plutons $\left(7.1\right.$ to $6.1 \mathrm{Ma}$ ) average $\varepsilon_{\mathrm{Hf}(\mathrm{t})}=+7.8$, while the younger Teniente Dacite Porphyry (5.3 Ma) has $\varepsilon_{\mathrm{Hf}(\mathrm{t})}=+7.2$ and the youngest latite dike $(4.8 \mathrm{Ma})$ has $\varepsilon_{\mathrm{Hf}(\mathrm{t})}=+6.9$ (Table 1$)$, so some small but significant temporal change, with decreasing $\varepsilon_{\mathrm{Hf}(\mathrm{t})}$ through time, is apparent.

Hf isotopic compositions were also determined in four barren Middle and Late Miocene plutonic complexes in the vicinity of El Teniente [50]. These can be divided into an older group ( 15 Ma) and a younger group (10 to $12 \mathrm{Ma}$ ), both groups being older than the felsic plutons within the El Teniente deposit (Figure 7). The older group is characterized by quartz monzogabbroic compositions with 54.0 to 57.5 wt. $\% \mathrm{SiO}_{2}$, while the younger group are quartz monzodioritic with higher $\mathrm{SiO}_{2}$ from 61.6 to 66.8 wt. \%. $\varepsilon_{\mathrm{Hf}(\mathrm{t})}$ for the older group ranges from +9.8 to +13.7 and averages +11.6 (Figure 7 ), while $\varepsilon_{\mathrm{Hf}(\mathrm{t})}$ for the younger group has a lower range of +7.6 to +8.5 and a lower average of +8.0 . These differences are also associated with increasing $\varepsilon_{\mathrm{Os}}$ from +32 to +160 for the older compared to the younger group. Both the Hf and Os isotopic data suggests increasing incorporation of crustal components with time, and the younger plutons, which have higher $\mathrm{SiO}_{2}$, are noteworthy for the presence of abundant mafic 
enclaves indicating intra-crustal (MASH) assimilation on a macroscopic scale. These are absent from the older plutonic group which have more primitive isotopic compositions and lower $\mathrm{SiO}_{2}$.

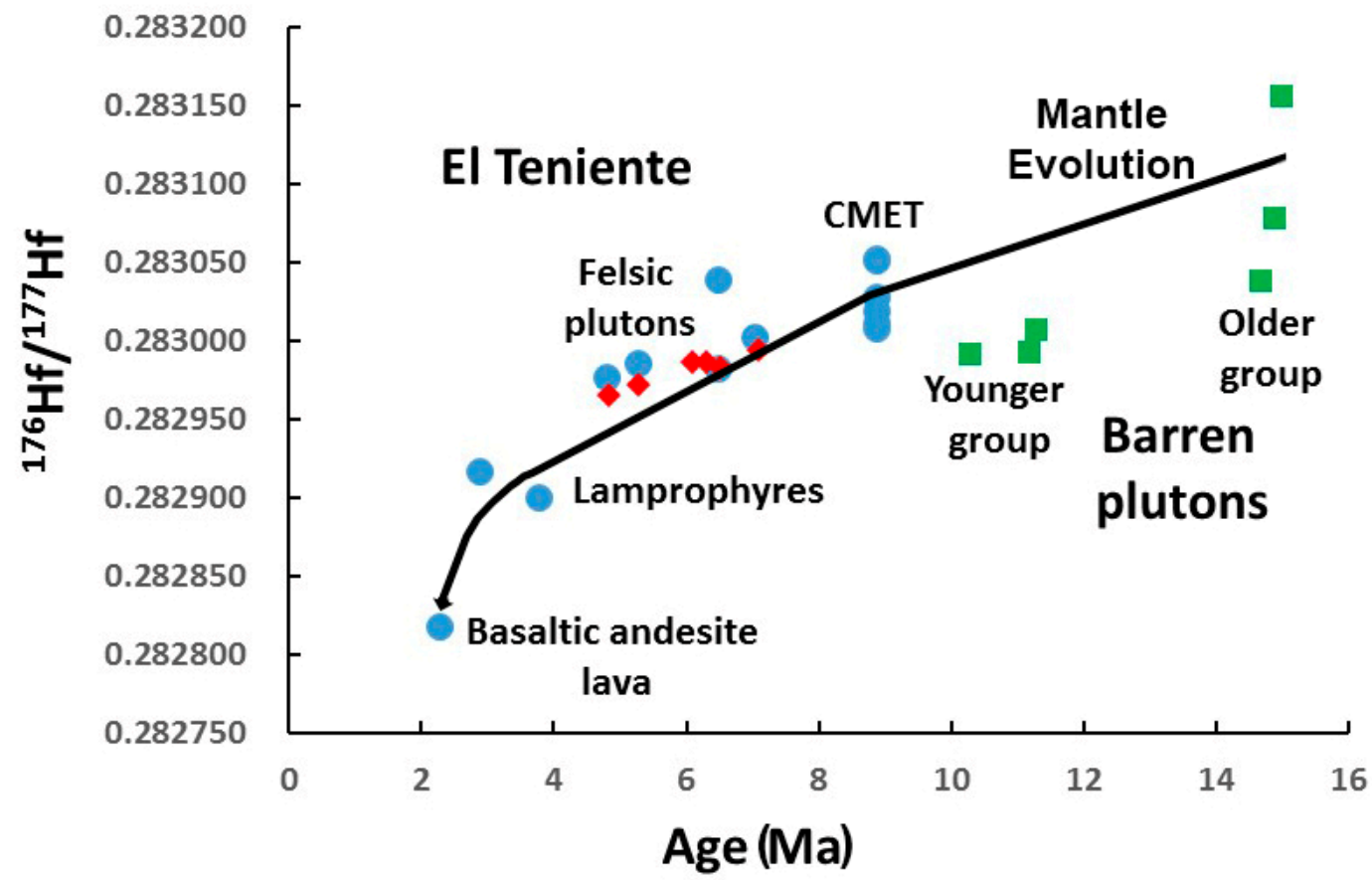

Figure 7. ${ }^{176} \mathrm{Hf} /{ }^{177} \mathrm{Hf}$ versus age (Ma) for samples from El Teniente (blue circles from Table 4; red diamonds from [28]) and Middle Miocene barren plutons in the same general area (green squares from [50]). The size of the symbols is greater than the error in the ${ }^{176} \mathrm{Hf} /{ }^{177} \mathrm{Hf}$ values. The mantle isotopic evolution line is drawn from the average of the older group of Middle Miocene barren plutons through the Late Miocene Teniente Mafic Complex (CMET) olivine basalts and gabbros, and then to the Pliocene olivine lamprophyres and olivine-bearing basaltic andesites, ignoring the younger group of barren plutons because these have macroscopic evidence for intra-crustal assimilation [50]. The amount of subducted crust plus sediment added to the mantle to generate this line is indicated in Figure 9.

Hf and $\mathrm{Nd}$ isotopic compositions have also been determined for five Late Miocene to Pliocene (8.3 to $\sim 3 \mathrm{Ma}$ ) plutons from the Eastern Principal Cordillera $\sim 40 \mathrm{~km}$ east of El Teniente (Figure 8; [24]). These have lower more radiogenic $\varepsilon_{\mathrm{Hf}(\mathrm{t})}(+4$ to -4$)$ and $\varepsilon_{\mathrm{Nd}}(+3$ to 0$)$ than the felsic plutons in $\mathrm{El}$ Teniente. Crustal-contamination (MASH) processes involving assimilation of Paleozoic and Mesozoic basement rocks are evidently involved in the genesis of the igneous rocks from the Eastern Cordillera (Figure 8), both because some contain zircon crystal with older (Paleozoic) inherited cores and others have wide ranges $(+1$ to -4$)$ of zircon $\varepsilon_{\mathrm{Hf}(\mathrm{t})}$ values [24]. However, it has also been suggested that the low $\varepsilon_{\mathrm{Nd}}$ values of the Pliocene olivine lamprophyres $(+1.2$ to +0.7$)$ and olivine-bearing basaltic andesites (-1.1; Figures 4 and 5; Table 1; [21-23]) emplaced in the Western Cordillera in the vicinity of El Teniente reflect a westward propagation of the Eastern Cordillera magmatic isotopic signatures, caused by westward thrusting and material transport of the Eastern Cordillera basement under the Western Cordillera in the Pliocene (Figure 8; [24]). We disagree with this interpretation as it fails to take into account the fact that the Pliocene high-Mg olivine lamprophyres, as well as the olivine-bearing basaltic andesite lavas, are likely to be mantle-derived, without significant crustal contamination. For high-Mg olivine lamprophyres in general, an origin by hydrous $\left(6-16 \mathrm{wt} . \% \mathrm{H}_{2} \mathrm{O}\right)$ melting of mantle has been suggested [51-55]. As discussed in more detail below, we therefore interpret the temporal change in both $\varepsilon_{\mathrm{Hf}(\mathrm{t})}$ and $\varepsilon_{\mathrm{Nd}}$ to lower more radiogenic values for Pliocene olivine-bearing mafic rocks associated with El Teniente in the Western Cordillera as reflecting a progressive change in mantle composition due to subduction of increased proportions of continental crust, and not to intra-crustal (MASH) contamination processes. 


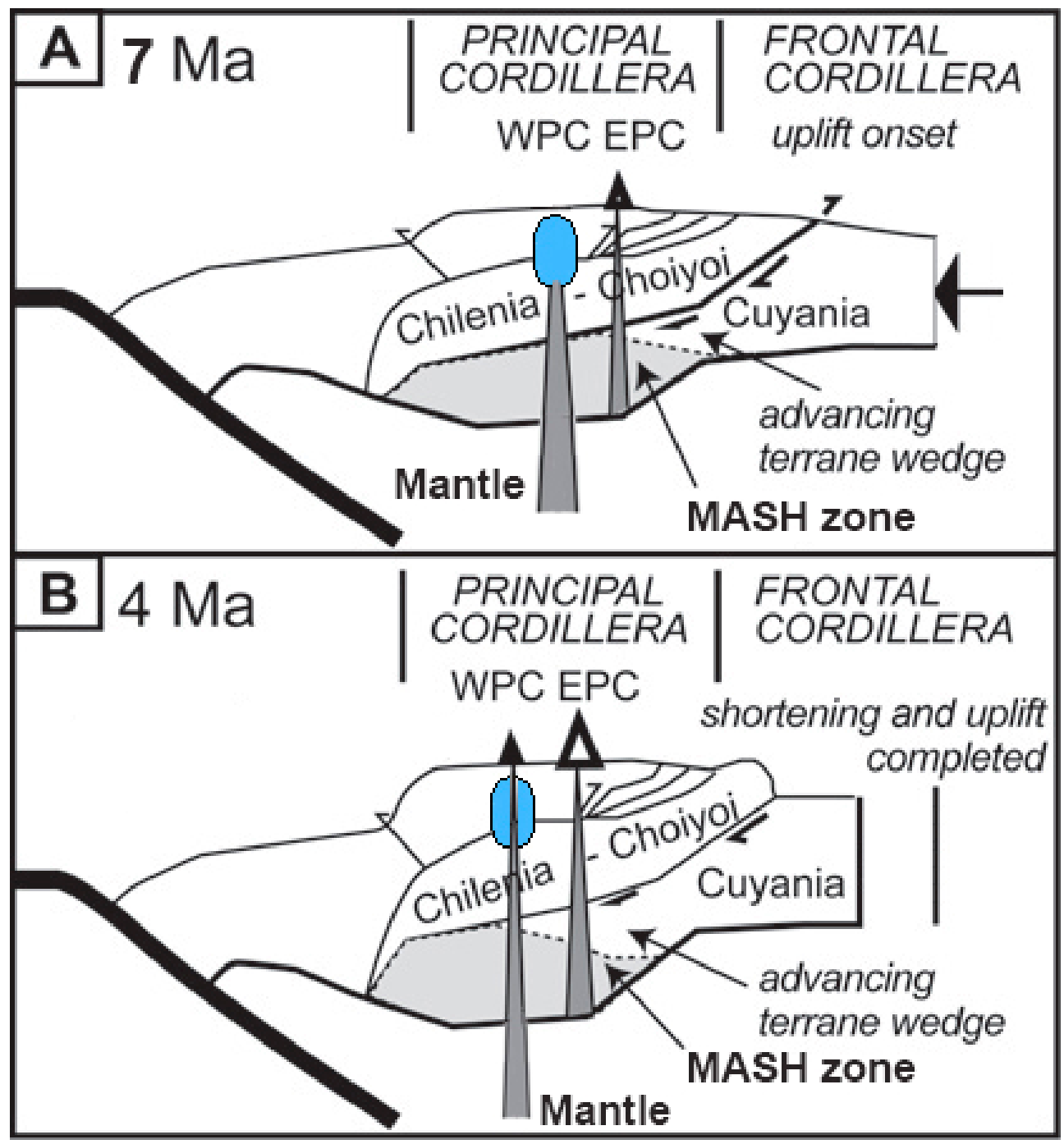

Figure 8. Schematic profiles [18-20,24] of crustal evolution of the Andes of central Chile and Argentina at $7 \mathrm{Ma}(\mathbf{A})$ and $4 \mathrm{Ma}$ (B). Evolution is characterized by increased shortening rates along the eastern flank of the orogenic belt after $7 \mathrm{Ma}$, where the Chilenia-Choiyoi block overrides the Cuyania terrane, producing uplift of the Frontal Cordillera. This also produced increasing crustal thickness, which led to uplift of the entire belt. Deformation amounts suggest that the Cuyania block descended immediately below the eastern part of the magmatic arc, changing composition of the base of the crust and thus changing the crustal magmatic source (MASH zone) below the Eastern Principle Cordillera (EPC). However, below the Western Principle Cordillera (WPC), mafic magmas continued to rise from the mantle without intra-crustal assimilation in a MASH zone. Between 7 and $4 \mathrm{Ma}$, these mantle-derived mafic magmas did not reach the surface, but were mixed, stored and homogenized in a large magma chamber (blue) below El Teniente. Within this chamber, the felsic plutons of the deposit developed without crustal assimilation and above it the mineralized breccias in the deposit were emplaced (see Figure 10). As subduction angle flattened and magma supply from the mantle decreased this chamber solidified. After $4 \mathrm{Ma}$, high-MgO olivine lamprophyres and olivine-bearing basaltic andesites, derived from a mantle hydrated and isotopically modified by increased proportions of subducted crust and sediment (Figure 7), rose through the now crystallized magma chamber, without any intra-crustal assimilation, to form dikes and lavas. (Reprinted from Geology, volume 41, Muñoz, M. et al., Isotopic shifts in the Cenozoic Andean arc of central Chile: records of an evolving basement throughout cordilleran arc mountain building, page 933, Copyright 2013, with fair use permission from the Geologic Society of America.). 
Finally, $\varepsilon_{\mathrm{Hf}(\mathrm{t})}$ values ranging from +6.9 to +9.6 were determined for 8 plutonic rocks between the ages of 28.1 and $11.5 \mathrm{Ma}$ from the region north of El Teniente between 32-33 ${ }^{\circ} \mathrm{S}$ [47]. The oldest sample, a dacite sill (sample Ab-143; $28.1 \mathrm{Ma}$ ), which has $\left({ }^{87} \mathrm{Sr} /{ }^{86} \mathrm{Sr}\right) \mathrm{i}=0.70661$ and is likely to have assimilated crustal material, has lower $\varepsilon_{\mathrm{Hf}(\mathrm{t})}$ of +7.8 than younger (22.2-17.7 Ma) gabbro, microgabbro and granodiorite samples which average $\varepsilon_{\mathrm{Hf}(\mathrm{t})}$ of +8.9 . All the still younger plutons have lower $\varepsilon_{\mathrm{Hf}}$ and the youngest (11.5 Ma; sample Z-132) has an $\varepsilon_{\mathrm{Hf}(\mathrm{t})}$ of +7.0 . This suggest decreasing $\varepsilon_{\mathrm{Hf}(\mathrm{t})}$ with time beginning after $\sim 17 \mathrm{Ma}$, and possibly before this time. Since these samples are all north of the current locus of subduction of the Juan Fernández Ridge, in an area where ridge subduction, decreasing subduction angle, eastward arc migration and increased rates of subduction erosion all happened earlier than at the latitude of El Teniente, we do not consider them appropriate for evaluating the temporal evolution of the mantle source of El Teniente magmatic rocks.

\section{Samples and Methods}

Twelve samples were selected for Hf-isotopic analysis (Tables 1-3). These range in age from $\geq 8.9$ to $2.3 \mathrm{Ma}$ and include (1) four samples from the Teniente Mafic Complex, including one olivine (Fo74) basalt, one gabbro and two other olivine-free basalts (Table 2); (2) five syn-mineralization felsic intrusions that range in age from 7.1 to $4.8 \mathrm{Ma}$ (Table 3), including four samples previously analyzed for Hf isotopes in zircon [28]; and (3) three post-mineralization samples that range in age from 3.8 to $2.3 \mathrm{Ma}$, including one high-MgO (7.9 wt. \%; Ni 190 and $\mathrm{Cr} \sim 390 \mathrm{ppm}$ ) olivine (Fo88) lamprophyre [22] and one olivine-bearing (Fo64) basaltic andesite (Table 2). All the sample have been previously analyzed for major and trace element contents and $\mathrm{Sr}$ and $\mathrm{Nd}$ isotopic compositions [21-23].

Ground sample weighing $\sim 200 \mathrm{mg}$ was decomposed in $15 \mathrm{~mL}$ screw-top Savillex Teflon ${ }^{\circledR}$ vials with a 1:1 mixture of $27 \mathrm{~N} \mathrm{HF}$ and $16 \mathrm{~N} \mathrm{HNO}_{3}$ at $\sim 150{ }^{\circ} \mathrm{C}$ for 5 days. The closed beakers were repeatedly placed in an ultrasonic bath during the course of digestion to enhance digestion efficiency. Each individual sample was carefully checked to make sure no visible solid residue was left in the Teflon beakers, and a clear solution was obtained for each run. The sample solutions were evaporated to incipient dryness and redissolved first by $2 \mathrm{~mL} 4 \mathrm{~N} \mathrm{HCl}$ and then by $1 \mathrm{~N} \mathrm{HCl}$. The dried samples were then taken into solution by $1 \mathrm{~mL} 2 \mathrm{~N} \mathrm{HCl}$ and $8 \mathrm{~mL} 6 \mathrm{~N} \mathrm{HCl}-0.2 \mathrm{~N} \mathrm{HF}$ prior to chemical separation. Hafnium was separated from the matrix elements by two columns packed with Ln-spec resin $(50-100 \mu \mathrm{m})$ from Eichrom Industries. Major elements and REE were eluted by $3 \mathrm{~N} \mathrm{HCl}$ and $6 \mathrm{~N} \mathrm{HCl}$, and then Ti and $\mathrm{Zr}$ were eluted using a $2 \mathrm{~N} \mathrm{HCl}-0.1 \mathrm{~N} \mathrm{HF}$ mixture. Hafnium was collected from the column with $2 \mathrm{~N} \mathrm{HCl}$ and $0.2 \mathrm{~N} \mathrm{HF}$, and was then evaporated to incipient dryness and taken up by $2 \mathrm{~N} \mathrm{HCl}-0.2 \mathrm{~N} \mathrm{HF}$. The chromatographic procedures were repeated again on the same column for further purification. Hafnium isotopes were measured on a Nu Plasma II multi-collector ICP-MS connected to an Aridus II desolvator and an enhanced sensitivity system with Ni 325-294 skimmer cone and Ni 319-646 sampler cone. The measured ${ }^{176} \mathrm{Hf} /{ }^{177} \mathrm{Hf}$ values were normalized for mass fractionation based on ${ }^{179} \mathrm{Hf} /{ }^{177} \mathrm{Hf}=0.7325$. Long-term mean value for the $\mathrm{Hf}$ standard JMC475 in the laboratory is ${ }^{176} \mathrm{Hf} /{ }^{177} \mathrm{Hf}=0.282164 \pm 8(\mathrm{n}=55)$. The ${ }^{176} \mathrm{Lu} /{ }^{177} \mathrm{Hf}$ ratio was calculated from the Lu and Hf contents determined by ICP-MS techniques by Activations Laboratories (Ancaster, ON, Canada). 
Table 2. Major and trace-element (in ppm) compositions of mafic rocks from El Teniente [21-23].

\begin{tabular}{|c|c|c|c|c|c|c|c|}
\hline \multirow[b]{2}{*}{ Sample } & \multicolumn{4}{|c|}{ Pre-Mineralization Samples $\geq 8.9$ Ma. } & \multicolumn{3}{|c|}{ Post-Mineralization Samples $\leq 3.9 \mathrm{Ma}$. } \\
\hline & EX2004-04 & $1411-1630^{\prime}$ & $540-2082^{\prime}$ & QT-4 & AS2003-01 & TTc-1 & PVF1 \\
\hline $\mathrm{SiO}_{2}$ & 51.94 & 51.08 & 51.3 & 49.65 & 51.31 & 56.30 & 56.50 \\
\hline $\mathrm{TiO}_{2}$ & 0.92 & 1.09 & 1.07 & 1.00 & 1.01 & 0.85 & 1.10 \\
\hline $\mathrm{Al}_{2} \mathrm{O}_{3}$ & 18.19 & 17.07 & 18.68 & 17.96 & 15.97 & 16.90 & 16.90 \\
\hline $\mathrm{Fe}_{2} \mathrm{O}_{3}$ & & 11.04 & 9.89 & & 7.82 & 3.60 & 2.70 \\
\hline $\mathrm{FeO}$ & 8.78 & & & 9.90 & & 2.00 & 5.10 \\
\hline $\mathrm{MnO}$ & 0.13 & 0.08 & 0.15 & 0.53 & 0.13 & 0.06 & 0.12 \\
\hline $\mathrm{MgO}$ & 5.71 & 5.75 & 5.23 & 5.29 & 7.92 & 3.30 & 4.80 \\
\hline $\mathrm{CaO}$ & 7.87 & 6.58 & 9.00 & 6.56 & 7.77 & 5.80 & 7.20 \\
\hline $\mathrm{Na}_{2} \mathrm{O}$ & 3.82 & 2.15 & 3.21 & 4.30 & 3.39 & 4.61 & 3.63 \\
\hline $\mathrm{K}_{2} \mathrm{O}$ & 1.01 & 2.56 & 1.00 & 1.03 & 1.06 & 1.60 & 2.10 \\
\hline $\mathrm{P}_{2} \mathrm{O}_{5}$ & 0.20 & 0.19 & 0.22 & 0.22 & 0.26 & 0.29 & 0.33 \\
\hline LOI & 0.98 & 1.46 & 1.07 & 4.53 & 2.04 & 5.10 & 0.68 \\
\hline Total & 99.55 & 99.05 & 100.82 & 100.97 & 98.66 & 100.41 & 101.16 \\
\hline Cs & 7 & 18 & 5.3 & 0.8 & 8.5 & 7.7 & 2.7 \\
\hline $\mathrm{Rb}$ & 26 & 159 & 54 & 29 & 21 & 40 & 60 \\
\hline $\mathrm{Sr}$ & 468 & 383 & 535 & 595 & 680 & 916 & 566 \\
\hline $\mathrm{Ba}$ & 235 & 100 & 158 & 310 & 345 & 460 & 471 \\
\hline $\mathrm{La}$ & 13.4 & 11.4 & 9.20 & 11.5 & 13.6 & 17.5 & 22.3 \\
\hline $\mathrm{Ce}$ & 30.3 & 26.4 & 20.3 & 26.5 & 31.0 & 40.6 & 50.0 \\
\hline $\operatorname{Pr}$ & 3.72 & 3.40 & 2.80 & 3.20 & 3.98 & 5.12 & \\
\hline $\mathrm{Nd}$ & 16.6 & 15.5 & 13.3 & 15.8 & 17.7 & 22.0 & 31.9 \\
\hline $\mathrm{Sm}$ & 4.00 & 3.71 & 3.30 & 3.90 & 3.90 & 4.09 & 6.52 \\
\hline $\mathrm{Eu}$ & 1.22 & 1.04 & 1.29 & 1.16 & 1.20 & 1.09 & 1.36 \\
\hline $\mathrm{Gd}$ & 3.70 & 3.11 & 3.50 & 3.40 & 3.30 & 3.07 & \\
\hline $\mathrm{Tb}$ & 0.60 & 0.51 & 0.60 & 0.60 & 0.50 & 0.38 & 0.66 \\
\hline Dy & 3.40 & 3.00 & 3.30 & 3.30 & 2.82 & 1.71 & \\
\hline Ho & 0.70 & 0.60 & 0.60 & 0.70 & 0.50 & 0.31 & \\
\hline $\mathrm{Er}$ & 1.90 & 1.60 & 1.90 & 2.00 & 1.50 & 0.84 & \\
\hline $\mathrm{Tm}$ & 0.28 & 0.24 & 0.30 & 0.27 & 0.21 & 0.13 & \\
\hline $\mathrm{Yb}$ & 1.70 & 1.48 & 1.70 & 1.60 & 1.29 & 0.80 & 2.32 \\
\hline $\mathrm{Lu}$ & 0.25 & 0.21 & 0.24 & 0.25 & 0.18 & 0.12 & 0.30 \\
\hline $\mathrm{Y}$ & 15 & 15 & 17 & 17 & 14 & 13 & 24 \\
\hline $\mathrm{Zr}$ & 86 & 56 & 73 & 74 & 110 & 129 & 196 \\
\hline $\mathrm{Hf}$ & 2.7 & 1.7 & 1.9 & 2.5 & 3.1 & 3.5 & 5.0 \\
\hline Th & 3.7 & 1.2 & 1.3 & 2.9 & 2.6 & 2.4 & 6.9 \\
\hline Sc & 21 & 30 & 27 & 24 & 23 & 11 & 18 \\
\hline $\mathrm{Cr}$ & 268 & 292 & 263 & 41 & 387 & 77 & \\
\hline $\mathrm{Ni}$ & 134 & 198 & 75 & 30 & 188 & 78 & \\
\hline $\mathrm{Cu}$ & 115 & 1325 & 204 & 20 & 94 & 85 & \\
\hline
\end{tabular}


Table 3. Major and trace-element (in ppm) compositions of felsic porphyries [23].

\begin{tabular}{|c|c|c|c|c|c|}
\hline Sample & Ttc5 & 1473-970' & $1446-266^{\prime}$ & $1300-403^{\prime}$ & 1394-92' \\
\hline $\mathrm{SiO}_{2}$ & 63.7 & 48.45 & 56.34 & 66.26 & 60.93 \\
\hline $\mathrm{TiO}_{2}$ & 0.39 & 1.01 & 0.42 & 0.38 & 0.63 \\
\hline $\mathrm{Al}_{2} \mathrm{O}_{3}$ & 17.1 & 18.62 & 13.86 & 16.85 & 17.24 \\
\hline $\mathrm{Fe}_{2} \mathrm{O}_{3}$ & 1.90 & 7.54 & 2.74 & 1.83 & 2.14 \\
\hline $\mathrm{FeO}$ & 2.40 & & & & \\
\hline $\mathrm{MnO}$ & 0.08 & 0.03 & 0.02 & 0.02 & 0.02 \\
\hline $\mathrm{MgO}$ & 1.50 & 4.73 & 1.41 & 1.01 & 1.86 \\
\hline $\mathrm{CaO}$ & 3.90 & 5.73 & 6.72 & 2.82 & 4.61 \\
\hline $\mathrm{Na}_{2} \mathrm{O}$ & 4.93 & 4.33 & 3.8 & 5.53 & 4.76 \\
\hline $\mathrm{K}_{2} \mathrm{O}$ & 2.20 & 3.63 & 5.68 & 2.64 & 2.23 \\
\hline $\mathrm{P}_{2} \mathrm{O}_{5}$ & 0.21 & 0.22 & 0.17 & 0.14 & 0.21 \\
\hline LOI & 1.80 & 4.66 & 7.99 & 1.95 & 5.74 \\
\hline Total & 100.17 & 100.39 & 102.49 & 99.43 & 100.37 \\
\hline Cs & 6.1 & 16.3 & 5.3 & 1.5 & 2.7 \\
\hline $\mathrm{Rb}$ & 96 & 209 & 187 & 66.7 & 80.5 \\
\hline $\mathrm{Sr}$ & 699 & 499 & 456 & 699 & 742 \\
\hline $\mathrm{Ba}$ & 528 & 244 & 601 & 644 & 311 \\
\hline $\mathrm{La}$ & 14.4 & 10.6 & 24.1 & 10.4 & 14.6 \\
\hline $\mathrm{Ce}$ & 34.7 & 21.4 & 53.7 & 20.1 & 30.9 \\
\hline $\operatorname{Pr}$ & 3.97 & 2.84 & 6.29 & 2.42 & 4.00 \\
\hline $\mathrm{Nd}$ & 19.2 & 13.43 & 26.12 & 9.00 & 15.3 \\
\hline $\mathrm{Sm}$ & 3.39 & 3.44 & 4.63 & 1.58 & 2.80 \\
\hline $\mathrm{Eu}$ & 0.88 & 1.00 & 0.79 & 0.65 & 0.83 \\
\hline $\mathrm{Gd}$ & 2.9 & 2.96 & 3.17 & 1.40 & 2.30 \\
\hline $\mathrm{Tb}$ & 0.29 & 0.51 & 0.38 & 0.20 & 0.20 \\
\hline Dy & 1.80 & 2.69 & 1.89 & 0.80 & 1.00 \\
\hline Ho & 0.30 & 0.50 & 0.34 & 0.18 & 0.20 \\
\hline Er & 0.90 & 1.39 & 0.94 & 0.50 & 0.50 \\
\hline $\mathrm{Tm}$ & 0.12 & 0.19 & 0.13 & 0.07 & 0.07 \\
\hline $\mathrm{Yb}$ & 0.92 & 1.12 & 0.79 & 0.40 & 0.40 \\
\hline $\mathrm{Lu}$ & 0.11 & 0.16 & 0.11 & 0.06 & 0.07 \\
\hline $\mathrm{Y}$ & 11 & 13 & 9 & 5 & 6 \\
\hline $\mathrm{Zr}$ & 94 & 95 & 81 & 94 & 108 \\
\hline $\mathrm{Hf}$ & 3.2 & 2.8 & 3.9 & 2.4 & 2.9 \\
\hline Th & 4.3 & 0.8 & 5.9 & 2.8 & 2.3 \\
\hline Sc & 6.0 & 21 & 2.6 & 4.0 & 8.0 \\
\hline $\mathrm{Cr}$ & 24 & $<20$ & $<20$ & 11 & 42 \\
\hline $\mathrm{Ni}$ & $<20$ & $<20$ & $<20$ & 34 & 86 \\
\hline $\mathrm{Cu}$ & 480 & 899 & 2380 & 6000 & 1250 \\
\hline
\end{tabular}

\section{Results}

The $\varepsilon_{\mathrm{Hf}(\mathrm{t})}$ determined on the bulk-rock samples of the 7.1 to $4.8 \mathrm{Ma}$ felsic plutons (Table 4) are similar within analytical error to those determined previously on zircons for the same plutons [28]. The good match of isotopic compositions indicates that Hf isotopes were not fractionated by any potential undigested phases. The $\varepsilon_{\mathrm{Hf}(\mathrm{t})}$ for all twelve samples ranges from an average of +9.1 for the four samples of $\geq 8.9 \mathrm{Ma}$ Teniente Mafic Complex basalts and gabbros down to +1.6 for the $2.3 \mathrm{Ma}$ olivine-bearing basaltic andesite lava flow (Table 4), which is the last manifestation of magmatic activity in the region of El Teniente prior to the eastward migration of the volcanic arc. This implies a drop of $7.5 \varepsilon_{\mathrm{Hf}(\mathrm{t})}$ units over this $6.6 \mathrm{~m}$.y. interval. Although Muñoz et al. [28] concluded that there was no change in $\varepsilon_{\mathrm{Hf}(\mathrm{t})}$ among the felsic plutons emplaced between 7.1 and $4.8 \mathrm{Ma}$, the new data for samples formed over the larger $\sim 6.6 \mathrm{~m}$.y. interval from $\geq 8.9$ to $2.3 \mathrm{Ma}$ indicates that there was a clear progressive decrease in $\varepsilon_{\mathrm{Hf}(\mathrm{t})}$ with decreasing age (Figure 7 ). 
Table 4. Lu-Hf isotopes of the El Teniente samples.

\begin{tabular}{|c|c|c|c|c|c|c|c|}
\hline Sample & Lu (ppm) & Hf (ppm) & ${ }^{176} \mathrm{Lu} /{ }^{177} \mathrm{Hf}$ & ${ }^{176} \mathrm{Hf} /{ }^{177} \mathrm{Hf}$ & $2 \sigma \times 10^{-6}$ & $\left({ }^{176} \mathrm{Hf} /{ }^{177} \mathrm{Hf}\right) \mathrm{i}$ & $\varepsilon_{\mathrm{Hf}(\mathrm{t})}$ \\
\hline \multicolumn{8}{|c|}{ Late Miocene ( $\geq 8.9 \mathrm{Ma}$ ) Pre-Mineralization Mafic Host Rocks } \\
\hline EX-2004-04 & 0.25 & 2.7 & 0.0131 & 0.283011 & 3.3 & 0.283009 & 8.6 \\
\hline 1411-1630' & 0.21 & 1.7 & 0.0175 & 0.283051 & 6.1 & 0.283048 & 9.9 \\
\hline $\begin{array}{c}\text { 1411-1630' } \\
\text { dup }\end{array}$ & 0.21 & 1.7 & 0.0175 & 0.283051 & 3.6 & 0.283048 & 10.0 \\
\hline $540-2082^{\prime}$ & 0.24 & 1.9 & 0.0179 & 0.283007 & 3.9 & 0.283004 & 8.4 \\
\hline $\begin{array}{l}\text { 540-2082' } \\
\text { dup }\end{array}$ & 0.24 & 1.9 & 0.0179 & 0.283027 & 4.2 & 0.283024 & 9.1 \\
\hline QT-4 & 0.25 & 2.5 & 0.0142 & 0.283018 & 3.4 & 0.283016 & 8.8 \\
\hline \multicolumn{8}{|c|}{ Late Miocene to Early Pliocene (7.1 to 4.8 Ma) Syn-Mineralization Felsic Plutonic Rocks } \\
\hline Ttc-5 & 0.11 & 3.2 & 0.0049 & 0.283001 & 11 & 0.283001 & 8.2 \\
\hline 1473-970' & 0.16 & 2.8 & 0.0081 & 0.283039 & 6.0 & 0.283038 & 9.5 \\
\hline $1446-266^{\prime}$ & 0.11 & 3.9 & 0.0040 & 0.282981 & 7.5 & 0.282981 & 7.5 \\
\hline $1300-403^{\prime}$ & 0.06 & 2.4 & 0.0036 & 0.282984 & 3.7 & 0.282984 & 7.6 \\
\hline 1394-92' & 0.07 & 2.9 & 0.0034 & 0.282976 & 2.8 & 0.282976 & 7.3 \\
\hline \multicolumn{8}{|c|}{ Pliocene (3.8 to 2.3) Post-Mineralization Olivine Lamprophyres and Basaltic Andesites } \\
\hline Ttc1 & 0.12 & 3.5 & 0.0049 & 0.282900 & 3.8 & 0.282899 & 4.6 \\
\hline AS-2003-1 & 0.18 & 3.1 & 0.0082 & 0.282916 & 3.1 & 0.282915 & 5.1 \\
\hline PVF1 & 0.30 & 5.0 & 0.0085 & 0.282817 & 2.3 & 0.282816 & 1.6 \\
\hline
\end{tabular}

Dup = duplicate.

Muñoz et al. [28] suggested that the full $\varepsilon_{\mathrm{Hf}(\mathrm{t})}$ range of +6 to +10 of the 7.1 to $4.8 \mathrm{Ma}$ felsic plutons is "identical to preceding Cenozoic barren magmatic activity in Central Chile". However, although their average $\varepsilon_{\mathrm{Hf}(\mathrm{t})}$ value of +7.4 (Table 1 ) is only somewhat lower than the younger group (10-12 Ma) of barren plutons, for which macroscopic and Os isotopic evidence of upper crustal assimilation has been documented, it is significantly lower than the older group ( 15 Ma; Figure 7). When the $\varepsilon_{\mathrm{Hf}(\mathrm{t})}$ of the older $\sim 15$ Ma group of barren plutons in the region, which average +11.6 [50], is taken into account, it is clear that $\varepsilon_{\mathrm{Hf}(\mathrm{t})}$ values have not remained constant through time (Figure 7). In fact, there has been an overall decrease of $10 \varepsilon_{\mathrm{Hf}(\mathrm{t})}$ units for igneous rocks emplaced in the vicinity of El Teniente in the 12.7 m.y. period from the Middle Miocene to the Pliocene.

\section{Discussion}

\subsection{Andean Magmagenesis}

The observed $10 \varepsilon_{\mathrm{Hf}(\mathrm{t})}$ unit decrease for igneous rocks emplaced in the vicinity of El Teniente in the 12.7 m.y. period from the Middle Miocene to the Pliocene is consistent with decreasing $\varepsilon_{\mathrm{Nd}(\mathrm{t})}$ from +5 to -1.1 , increasing ${ }^{87} \mathrm{Sr} /{ }^{86} \mathrm{Sr}$ (i) from 0.70376 to 0.70485 , and increasing ${ }^{206} \mathrm{~Pb} /{ }^{204} \mathrm{~Pb}$ from 18.55 to 18.68 determined for these same samples (Figures 4 and 5; [21-23]). These variations imply increasing incorporation of continental crust through time in the magmas that formed these rocks.

The fact that the samples include mantle-derived olivine basalts and high-Mg olivine lamprophyres suggests that these continental components were incorporated into their mantle source, and not by intra-crustal contamination (MASH). This suggestion is supported by two other lines of evidence. One is that for all the rocks of variable $\mathrm{SiO}_{2}$ content within the igneous associations of specific ages identified in the area of $\mathrm{El}$ Teniente, the isotopic compositions do not vary as $\mathrm{SiO}_{2}$ increases (Figure 5). The isotopic compositions of the different associations vary through time, but not as a function of $\mathrm{SiO}_{2}$. This implies that crystal fractionation processes are not combined with intra-crustal assimilation in the generation of the range of rocks from basalts through rhyolites formed during each of these successive magmatic events. Second, models of intra-crustal assimilation (MASH) for $\mathrm{Sr}$ and $\mathrm{Nd}$ isotopes (Figure 4; [21-23]) indicate that relatively large proportions ( $>40 \mathrm{wt} . \%$ ) of crust must be 
assimilated to produce the $\mathrm{Sr}$ and $\mathrm{Nd}$ isotopic changes observed between mid-Tertiary basalts and Pliocene olivine lamprophyres and olivine-bearing basaltic andesites. This is considered to be an unacceptably large amount of crust to be assimilated in olivine-bearing mafic magmas.

In contrast, models of mantle source region contamination by subducted crustal components indicates that the $\mathrm{Sr}$ and $\mathrm{Nd}$ isotopic evolution of the subarc mantle source of the mafic magmas erupted in the vicinity of El Teniente between the mid Tertiary and Pliocene can be produced by the incorporation of increased, but still relatively small proportions of subducted crust and sediment (Figures 4 and 5; [3,10,21-23]). Mid Tertiary Coya-Machali group mafic volcanic rocks require the addition to a primitive subarc mantle of only $1 \mathrm{wt}$. \% subducted crust and sediment, while Pliocene olivine lamprophyres and basaltic andesites require the addition of between $4-6 \mathrm{wt}$. \% subducted crust to produce an appropriately isotopically modified mantle source.

The difference between these intra-crustal assimilation and mantle source region contamination models reflects the relatively high $\mathrm{Sr}(450 \mathrm{ppm})$ and $\mathrm{Nd}(9 \mathrm{ppm})$ contents of a basalt relative to the crust being assimilated, thus requiring a relatively large proportion of crust to produce the appropriate isotopic leverage. In contrast the low $\mathrm{Sr}(36 \mathrm{ppm})$ and $\mathrm{Nd}(1.8 \mathrm{ppm})$ contents of the mantle allows a much smaller proportion of subducted crust and sediment to produce the same isotopic leverage (Figures 4 and 5; [3-5,10,21-23]). For the Hf isotopic system, the same logic applies. The olivine basalts and gabbros of the Teniente Mafic Complex contain an average of 2 ppm Hf (Table 4), while average upper continental crust contains $5.3 \mathrm{ppm}$ and bulk continental crust $3.7 \mathrm{ppm}$ Hf [56]. In contrast, primitive mantle contains only $0.28 \mathrm{ppm} \mathrm{Hf} \mathrm{[57],} \mathrm{so} \mathrm{the} \mathrm{proportion} \mathrm{of} \mathrm{crust} \mathrm{needed} \mathrm{to} \mathrm{modify} \mathrm{the} \mathrm{Hf}$ isotopic composition of the mantle is small compared to that needed to be assimilated by a basalt.

Since the mantle source region contamination model better explains the $\mathrm{Sr}$ and $\mathrm{Nd}$ isotopic evolution through time of the same olivine-bearing mafic rocks that we have analyzed for Hf isotopes, we also interpret the temporal change in their Hf isotopic compositions to reflect the isotopic evolution of their mantle source affected by increased incorporation of subducted crust and sediment. To quantitatively evaluate the amount of source region contamination to produce these Hf isotopic variations is complicated for two reasons. The first is the inherent complexities involved in subduction zone magmatism, such as the amounts of pelagic, terrigenous and tectonically eroded continental crust being subducted, and the uncertainty in the processes of transfer of these components into the overlying mantle wedge by either dehydration and volatile transport, melting or diapiric uprise of these low density materials. The second is that information is not available for the Hf contents and isotopic compositions of all these different components relevant to magmagenesis in the vicinity of $\mathrm{El}$ Teniente, in particular for the coastal and offshore Paleozoic and early Mesozoic crustal rocks being tectonically eroded and subducted.

In the central Mexican magmatic belt, west of where subduction erosion rates are estimated as $79-88 \mathrm{~km}^{3} / \mathrm{km} / \mathrm{m}$.y., and where Hf concentration and isotopic data are available for both pelagic and terrigenous sediment, as well as coastal continental rocks, Straub et al. [58] concluded that tectonically eroded continental crust, consisting of coastal and off-shore granodiorite plutons, was the dominant control on the isotopic composition of the calc-alkaline arc magmas, and that neither intra-crustal assimilation nor subducted trench sediment played a significant role in the genesis of these magmas. For the El Teniente rocks, we calculated a model assuming for Hf contents the average estimated values for primitive mantle and the average upper crust for the subducted crust and sediment, as well as a low crustal ${ }^{176} \mathrm{Hf} /{ }^{177} \mathrm{Hf}$ isotopic ratio similar to that determined by Straub et al. [58] for Mexican basement biotite gneisses (Table 5). This model can generate results (Figure 9) consistent with those previously determined for the $\mathrm{Sr}$ and $\mathrm{Nd}$ isotopic systems for which more published values for the materials involved in Andean magmagenesis are available [10,21-23]. These models all indicate that the addition of $1 \mathrm{wt}$. \% subducted crust and sediment can produce an isotopically modified mantle appropriate for the generation of the mid Tertiary Coya-Machali basalts. Addition of progressively greater amounts of 2, 4 and $6 \mathrm{wt}$. \% subducted crust and sediment is required to further modify the 
mantle to produce the Late Miocene Teniente Mafic Complex olivine basalts and gabbros, the Pliocene olivine lamprophyres and younger Pliocene basaltic andesites, respectively.

Table 5. Parameters used for the mantle modified by subducted crust + sediment model [22].

\begin{tabular}{ccc}
\hline Element and Isotopes & Mantle & Crust + Sediment \\
\hline $\mathrm{Sr} \mathrm{ppm}$ & 36 & 380 \\
${ }^{87} \mathrm{Sr} /{ }^{86} \mathrm{Sr}$ & 0.7030 & 0.70763 \\
$\mathrm{Nd} \mathrm{ppm}$ & 1.8 & 42.3 \\
${ }^{143} \mathrm{Nd} /{ }^{144} \mathrm{Nd}$ & 0.51300 & 0.51235 \\
$\mathrm{Hf} \mathrm{ppm}$ & 0.28 & 5.3 \\
${ }^{176} \mathrm{Hf} /{ }^{177} \mathrm{Hf}$ & 0.28320 & 0.28256 \\
\hline
\end{tabular}

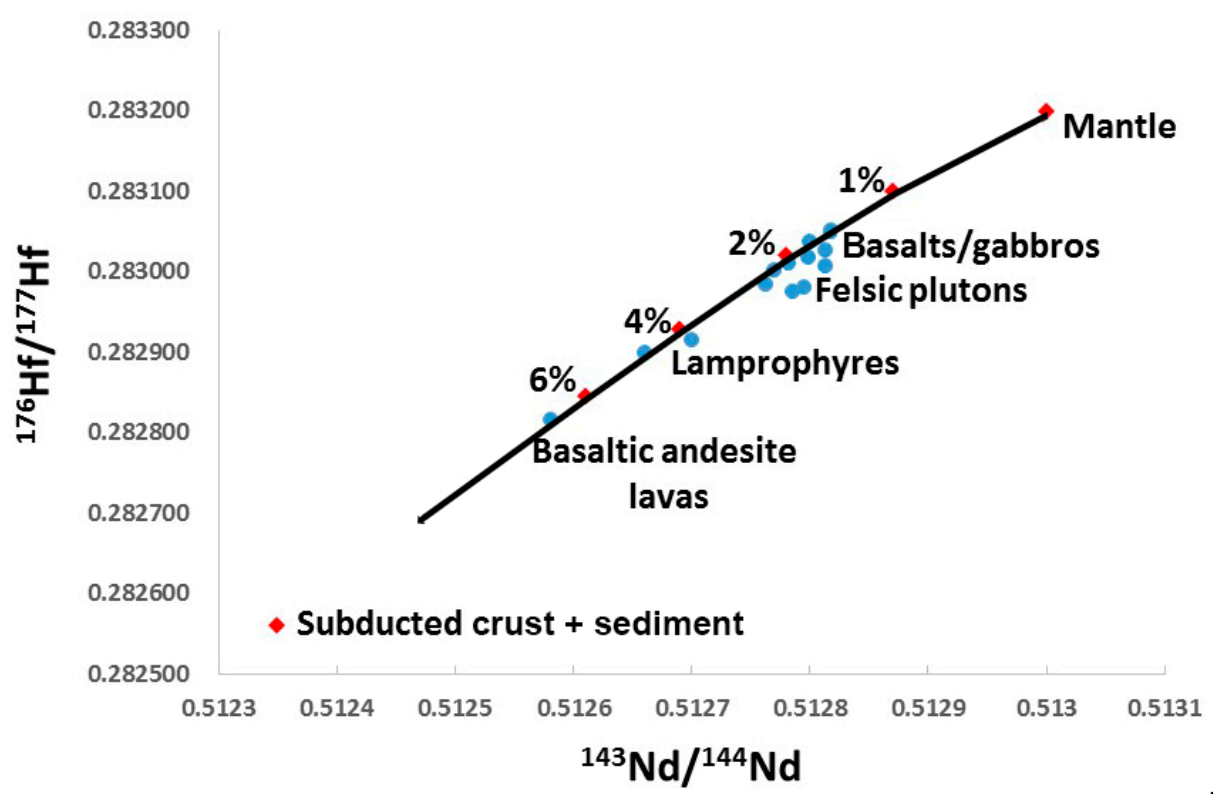

Figure 9. ${ }^{176} \mathrm{Hf} /{ }^{177} \mathrm{Hf}$ versus ${ }^{143} \mathrm{Nd} /{ }^{144} \mathrm{Nd}$ for samples from El Teniente (Table 4; blue circles) compared to isotopic values of a primitive mantle (Table 5) modified by the addition of various proportions (red diamonds) of subducted crust and sediment.

What can be said unequivocally in support of this model of the isotopic evolution of the subarc mantle underlying El Teniente is that the rate of subduction erosion and amount of Paleozoic and early Mesozoic crust being subducted did increase between the mid Tertiary and Pliocene as the locus of subduction of the Juan Fernández Ridge migrated southward. Prior to impingement of the ridge on the northern end of the SVZ, subduction erosion rates may have been similar to those estimated presently for the central SVZ of $35 \mathrm{~km}^{3} / \mathrm{km} / \mathrm{m} . \mathrm{y}$. (Figure 2; [5]). Over the last $10 \mathrm{~m} . \mathrm{y}$., as the ridge approached it current position at the northern end of the SVZ (Figures 2 and 3; [26,27]), rates of subduction erosion west of El Teniente increased to possibly as high as between 115 and 230 $\mathrm{km}^{3} / \mathrm{km} / \mathrm{m}$.y. [5]. This increased rate of subduction erosion must be considered as the most probable cause for the increasingly crustal $\mathrm{Hf}, \mathrm{Sr}, \mathrm{Nd}$ and $\mathrm{Pb}$ isotopic signatures in the igneous rocks associated with the El Teniente deposit through time.

A second important factor that changed over the same time period, was that the angle of subduction decreased, thus contributing, along with subduction erosion, to the $\sim 50 \mathrm{~km}$ eastward migration of the Andean arc in the Pliocene (Figure 3; $[10,25]$ ). Decreasing subduction angle reduced the volume of the subarc mantle wedge and resulted in a progressive decrease in the volume of magmas being produced prior to arc migration. Even if the amount of crustal components transferred from the subducted slab into the mantle wedge remained the same through time, which it did not since subduction erosion rates increased, the decreasing volume of the wedge would result in these components becoming 
progressively more significant within the wedge. Stern [3-5] and Kay et al. [10] have shown that the decreasing volume of magma erupted in the vicinity of El Teniente through time from the mid Tertiary to Pliocene is consistent with decreasing percent of mantle partial melting as the angle of subduction decreased. This resulted in increasing Sr contents, from 450 to $700-900 \mathrm{ppm}$ in association with increasing ${ }^{87} \mathrm{Sr} /{ }^{86} \mathrm{Sr}$ ratios in the sequence of mid Tertiary basalts to Pliocene olivine bearing mantle-derived lamprophyres [22]. Decreased degrees of mantle partial melting may also explain the somewhat higher Hf contents of the small volume of Pliocene olivine lamprophyres ( $>3 \mathrm{ppm}$ ) and basaltic andesite lavas (5 ppm) compared to the older Teniente Mafic Complex olivine basalts and gabbros ( 2 ppm; Table 4). Lamprophyres in general have been attributed to small degrees, relative to basalts, of partial melting of hydrated (6 to $16 \mathrm{wt}$. \% $\mathrm{H}_{2} \mathrm{O}$ ) mantle [51-55], $\mathrm{H}_{2} \mathrm{O}$ being one of the subducted components likely to increase in significance in the mantle wedge as mantle volume decreases.

In summary, the $\mathrm{Hf}$ isotopic data are consistent with $\mathrm{Sr}, \mathrm{Nd}$ and $\mathrm{Pb}$ isotopic data, and suggest the incorporation of small but progressively increasing proportions of continental crust in the mantle source of the mafic magmas erupted in the vicinity of El Teniente between 15 and $2.3 \mathrm{Ma}$. Trench sediment recycling has been confirmed by the detection of cosmogenic ${ }^{10} \mathrm{Be}$ in many, including Andean arc, lavas [59-61], and comprehensive trace-element and isotopic studies have also provided evidence for the incorporation of fore-arc eroded crust in the subarc mantle source of both Andean $[3-5,7,8,10,11]$ and arc volcanoes along other convergent plate boundaries [58,62-64]. The model developed for the El Teniente area suggests that increasing rates of subduction erosion through time has resulted in variable, but nevertheless relatively small ( 1 to $\leq 6 \mathrm{wt}$. \%), amounts of subducted crust having significantly affected the isotopic composition of the mantle source of the mafic magmas through time. Models for magmagenesis in other arcs, for instance the central Mexican volcanic belt, have suggested much larger amounts of recycled crust involved in the generation of both mafic and intermediate arc magmas; from $>60 \%$ in conjunction with diapiric uprise and melting of subducted crust [58] to $100 \%$ resulting in the generation of andesites by bulk melting of subducted crust "relaminated" below the mantle wedge [63].

\subsection{El Teniente Deposit}

The giant El Teniente $\mathrm{Cu}-\mathrm{Mo}$ deposit originally contained $\geq 100$ million metric tonnes (Mt) of $\mathrm{Cu}[33,34] . \mathrm{Pb}, \mathrm{S}$ and $\mathrm{Os}$ isotopic data $[43-45,65]$ indicate that $\mathrm{Cu}, \mathrm{Mo}$ and $\mathrm{S}$ were derived from the associated igneous rocks. $\mathrm{O}$ and $\mathrm{H}$ isotopic and fluid inclusion data suggest that these metals were transported and deposited by high-temperature magmatic fluids $[38,39,66]$, and a significant proportion of the $\mathrm{Cu}$ ore is contained with magmatic-hydrothermal breccia pipes [33-37]. Important questions concerning the genesis of El Teniente, and any other giant orthomagmatic ore deposit, are: (1) Was the large amount of metal in the deposit derived from a large amount of magma or a unique metal-rich magma?; and (2) How were the metals transferred from the magma into the host rocks?

Muñoz et al. [28] conclude that the high initial $\varepsilon_{\mathrm{Hf}(\mathrm{t})}$ values (total average of +7.4 ) of the syn-mineralization felsic plutons "rules out involvement of any significant crustal contamination in the genesis of the El Teniente magmas". We agree, at least with regard to intra-crustal assimilation (MASH). However, they then go on to suggest that, based "entirely on the near constant Hf isotopic composition shown by the Cenozoic igneous of the region", they also "envision that Cenozoic magmatism in central Chile originates from a MASH reservoir". We strongly disagree, given the clear evidence that the $\varepsilon_{\mathrm{Hf}(\mathrm{t})}$ values of Cenozoic magma, in particular mantle-derived mafic magmas erupted in the region, were not at all constant, but progressively decreased significantly with time.

We suggest instead that the near constancy of the Hf isotopic composition of the 7.1 to $4.8 \mathrm{Ma}$ felsic plutons in the El Teniente deposit is a result of mixing, storage and homogenization (but not crustal assimilation) of mantle-derived magmas in a large vertically zoned upper crustal magma chamber (Figure 10) which developed as a result of compressive deformation after $7 \mathrm{Ma}$ (Figure 8). These mafic mantle-derived magmas provided heat, water, $\mathrm{S}$ and metals into the base of this magma 
chamber [67], which became vertically stratified with more hydrous and more silica-rich magmas closer to the surface. As the input of mantle-derived magmas decreased during the Late Miocene, and uplift and erosion brought the roof of the chamber closer to the surface [12,13], the upper part of the chamber crystallized and differentiated into the magmas that formed the felsic plutons. Although the Hf isotopic composition of the mantle-derived magmas may have been evolving over this same time period (Figure 7), the large volume of the magma chamber into which these magmas mixed limited the variations observed within the progressively younger felsic plutons, although some small decrease in their $\varepsilon_{\mathrm{Hf}(\mathrm{t})}$ values is apparent. Once this large magma chamber had fully crystallized, mantle-derived olivine lamprophyre dikes were able to penetrate up to the surface, and these clearly exhibit lower $\varepsilon_{\mathrm{Hf}(\mathrm{t})}$ resulting from increased source region contamination of the mantle by subducted components. Small barren plutons of the Young Plutonic Complex (5.5 to 6 Ma; Figure 5; [10]), which occur outside the area of the deposit, also have more radiogenic characteristics than the felsic porphyries of similar age within the deposit, presumably because they have not formed above such a large, long-lived magma chamber and their isotopic compositions reflect more directly that of the mantle-derived magmas that they were derived from. This is consistent with the suggestion that the difference between barren plutons and the mineralized deposit reflects the size and longevity of the magma chambers that lead to their formation.
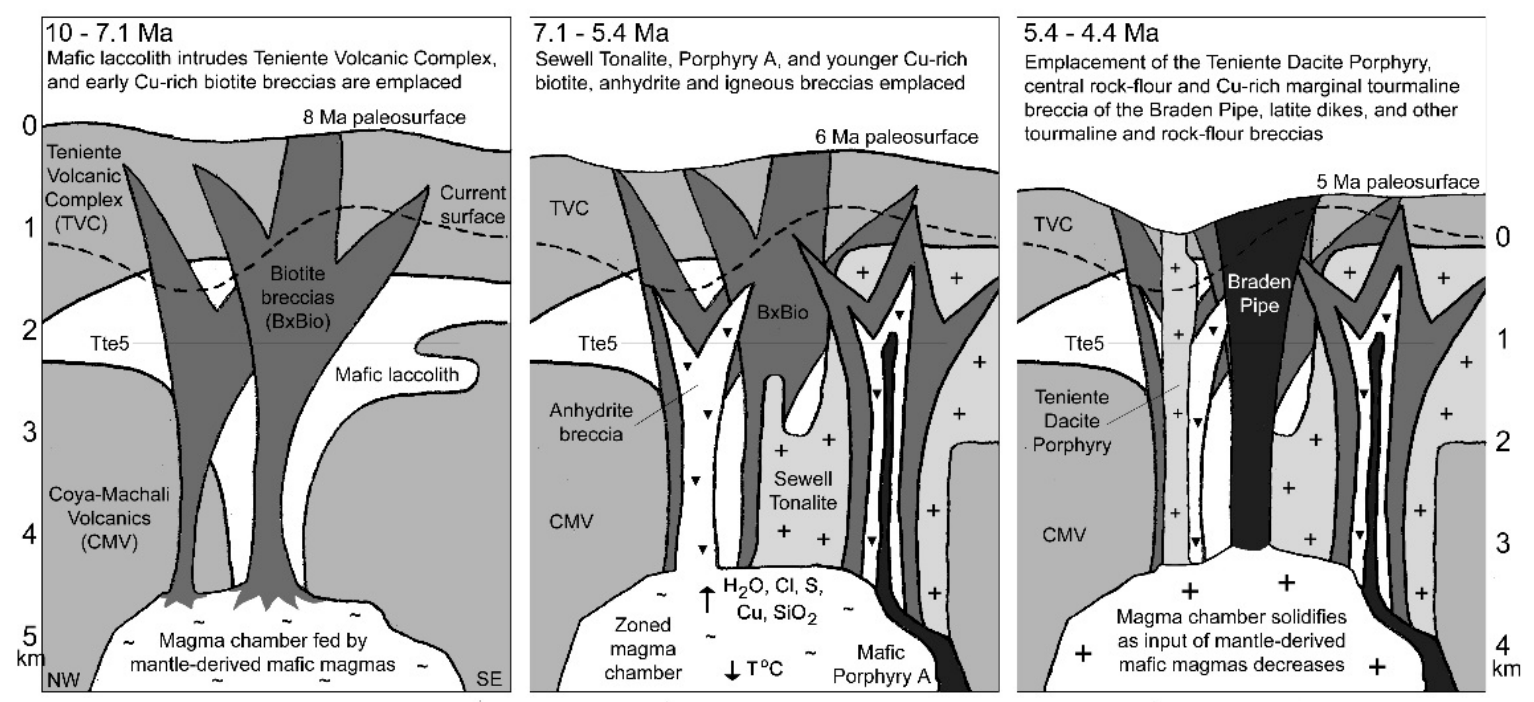

Figure 10. Model for the multistage development of the El Teniente deposit $[23,33,34,39]$. The main features of the model include (1) a large, long-lived ( $\geq 3 \mathrm{Myr}$ ) open-system magma chamber, crystallizing at $\geq 4 \mathrm{~km}$ depth, fed from below by mantle-derived mafic magmas and exsolving mineral-rich high-temperature magmatic fluids through its roof to produce the large breccia pipes that are prominent features this deposit; (2) decreasing magma supply in the Late Miocene and Pliocene as subduction angle decreases, leading to crystallization and solidification of this chamber; (3) progressive uplift and erosion that enhances this crystallization and solidification process and results in telescoping of different types of breccia and igneous rocks [12,13]; (4) progressive igneous differentiation of the magma chamber associated with crystallization and volatile loss, generating felsic porphyries that intrude previously mineralized rocks above the chamber. No coeval volcanism is known to have occurred during mineralization, but once the chamber solidified, post-mineralization mantle-derived olivine lamprophyre dikes were emplaced. (Reprinted from Journal of Petrography, volume 52, Stern, C.R. et al., Magmatic evolution of the giant El Teniente Cu-Mo deposit, central Chile, page 1607, Copyright 2011, with permission from Oxford University Press.).

Muñoz et al. [28] further suggest that, as a result of crustal thickening, dehydration melting in the deep crustal hot zone [68] within which the MASH reservoir was located "probably influenced the fertility of the magmas by increasing the melt component derived from this process relative to 
the component derived from primary" mantle melts. They do not detail what specific characteristics make a magma more "fertile", but they note that dehydration melting leads to the development of water undersaturated magmas, which are less, not more likely to be able to exsolve mineral-rich magmatic fluids.

In contrast, we conclude that the mantle-derived olivine basalts emplaced in the Teniente Mafic Complex prior to the development of the large magma chamber below the deposit, and the mantle-derived olivine lamprophyres which cut through the deposit after this magma chamber fully solidified, have changed their isotopic compositions due to increased contamination of the mantle source region with subducted components, but we do not observe [22,23] any significant change in the $\mathrm{Cu}$ contents between the pre-mineralization olivine basalts $(\sim 100 \mathrm{ppm})$ and the post-mineralization olivine lamprophyres ( 100 ppm). Therefore, we do not believe that source region contamination generated a uniquely "fertile" magma with respect to $\mathrm{Cu}$ content, although it did increase the $\mathrm{H}_{2} \mathrm{O}$ content of the mantle. We have suggested instead that the large amount of $\mathrm{Cu}$ in the deposit reflects a large amount of magma in the chamber above which the deposit developed $[38,39,69,70]$. To produce the $\geq 100 \times 10^{6}$ tonnes of $\mathrm{Cu}$ in the deposit requires a batholith-sized $\left(\geq 600 \mathrm{~km}^{3}\right)$ amount of magma with $\sim 100 \mathrm{ppm} \mathrm{Cu}$. What made the deposit giant was that over the $\sim 3 \mathrm{~m}$.y. period that a magma chamber existed below the developing deposit, $\mathrm{Cu}, \mathrm{S}$ heat and water from mantle derived magmas were added continuously to the base of the chamber and subsequently concentrated near the roof of the chamber by volatile transport. Clearly, because of increased source region contamination by subducted materials the mantle wedge did also became progressively more hydrated, ultimately leading to the generation of lamprophyric magmas, which require 6-16 wt. $\% \mathrm{H}_{2} \mathrm{O}$, instead of olivine basalts, which require only 2 wt. $\% \mathrm{H}_{2} \mathrm{O}$ [52-55]. Increasing $\mathrm{H}_{2} \mathrm{O}$ content of the mantle-derived magmas through the time that they were mixed into the overlying magmas chamber may have resulted in more oxidizing conditions within the chamber, enhancing the process of volatile transfer of $S$ and metals towards the roof of the chamber (Figure 10; [49,51,71]).

Older studies of El Teniente suggested that $\mathrm{Cu}$ was transferred into the host rocks in association with the intrusion of the Teniente Dacite Porphyry, but new age dates indicate that much of the mineralization precedes this event, and that where this essentially barren porphyry intrudes outside the deposit, it creates only alteration but not mineralization. Instead we have suggested that the $\mathrm{Cu}$ and $S$ were transferred into the host rocks of the deposit from the roof of the large magma chamber by exsolution of high-temperature metal-rich fluids generating multiple large magmatic-hydrothermal mineralized breccia complexes such as the central Braden Pipe, and El Teniente is thus better classified as a megabreccia deposit (Figure 10; [23,33,34,38,39]. Vry et al. [37] proposed that such breccias formed in association with the intrusion of the small dacite and diorite dikes to the northeast of the Braden pipe (Figure 6). However, we suggest instead that the breccias formed first and the porphyries intruded into the zone of weakness created by the breccias, since some of these porphyry bodies, such as Porphyry A (Figure 6) contain clasts of the breccias they intrude, and others of these small porphyries have no associated breccias surrounding them.

\section{Conclusions}

The Hf isotopic data are consistent with the $\mathrm{Sr}, \mathrm{Nd}$ and $\mathrm{Pb}$ data, and imply the incorporation of small, but progressively increasing proportions of continental crust into the mantle source of the mafic magmas erupted in the vicinity of El Teniente between $\geq 15$ and 2.3 Ma.

The felsic plutons in the deposit formed by mixing, storage and homogenization, combined with crystal-liquid differentiation, but not crustal assimilation (not MASH), in a large, long-lived, vertically zoned magma chamber that developed due to compressive deformation and persisted between the period $\sim 7$ to $4.6 \mathrm{Ma}$.

Progressively more hydrous and radiogenic mantle-derived mafic magmas feed this chamber from below, providing heat, $\mathrm{H}_{2} \mathrm{O}, \mathrm{S}$ and metals, but no unique "fertile" $\mathrm{Cu}$-rich magma was involved in the formation of the deposit. 
As the volume of these mantle-derived magmas decreased from the Late Miocene into the Pliocene, the chamber crystallized and solidified, producing both felsic plutons and large magmatic-hydrothermal breccias that emplaced $\mathrm{Cu}$ and $\mathrm{S}$ into the older $(\geq 8.9 \mathrm{Ma})$ mafic Teniente Mafic Complex host rocks of the deposit. The deposit is, therefore, best classified as a megabreccia deposit.

Author Contributions: Conceptualization, C.R.S., M.A.S. and A.A.; Data curation, K.-N.P. and H.-Y.L.; Project administration, C.R.S., M.A.S. and A.A.; Writing-original draft, C.R.S.; Writing-review and editing, K.-N.P., H.-Y.L., M.A.S. and A.A.

Funding: The analytical work was supported by Ministry of Science and Technology, Republic of China (Taiwan) grant MOST 105-2628-M-001-002-MY4 to K.-N.P.

Acknowledgments: We thank Patricio Zuñiga, Ricardo Floody, Domingo Espiñeira and René Padilla for collaboration in the collection and characterization of the samples from El Teniente, and two reviewers for their constructive comments.

Conflicts of Interest: We have no conflicts of interests.

\section{References}

1. Hickey-Vargas, R. Peeled or MASHed? Nature 1991, 350, 381-382. [CrossRef]

2. Hildreth, W.; Moorbath, S. Crustal contributions to arc magmatism in the Andes of central Chile. Contrib. Mineral. Petrol. 1988, 103, 361-386. [CrossRef]

3. Stern, C.R. Role of subduction erosion in the generation of Andean magmas. Geology 1991, 19, $78-81$. [CrossRef]

4. Stern, C.R. Active Andean volcanism: Its geologic and tectonic setting. Rev. Geol. Chile 2004, 31, 161-208. [CrossRef]

5. Stern, C.R. Subduction erosion: Rates, mechanisms, and its role in arc magmatism and the evolution of the continental crust and mantle. Gondwana Res. 2011, 20, 284-308. [CrossRef]

6. Rutland, R.W.R. Andean orogeny and ocean floor spreading. Nature 1971, 233, 252-255. [CrossRef]

7. Goss, A.R.; Mahlburg Kay, S.; Mpodozis, C. Andean adakite-like high-Mg andesites on the Northern margin of the Chilean-Pampean flat-slab $\left(27-28.5^{\circ} \mathrm{S}\right)$ associated with frontal arc migration and fore-arc subduction erosion. J. Petrol. 2013, 54, 2193-2234. [CrossRef]

8. Risse, A.; Trumbull, R.B.; Kay, S.M.; Coira, B.; Romer, R.L. Multi-stage evolution of Late Neogene mantle-derived Magmas from the Central Andes Back-arc in the Southern Puna Plateau of Argentina. J. Petrol. 2013, 10, 1963-1995. [CrossRef]

9. Lamb, S.; Davis, P. Cenozoic climate change as a possible cause for the rise of the Andes. Nature 2003, 425, 792-797. [CrossRef]

10. Kay, S.M.; Godoy, E.; Kurtz, A. Episodic arc migration, crustal thickening, subduction erosion, and magmatism in the south-central Andes. Geol. Soc. Amer. Bull. 2005, 117, 67-88. [CrossRef]

11. Holm, P.M.; Søager, N.; Thorup-Dyhr, C.; Rohde-Nielsen, M. Enrichments of the mantle sources beneath the Southern Volcanic Zone (Andes) by fluids and melts derived from abraded upper continental crust. Contrib. Mineral. Petrol. 2014, 167, 1004. [CrossRef]

12. Skewes, M.A.; Holmgren, C. Solevantamiento Andino, erosión y emplazamiento de brechas mineralizadas en el depósito de cobre porfídico Los Bronces, Chile Central (33 S): Aplicación de termometría de inclusiones fluidas. Rev. Geol. Chile 1993, 20, 71-84. (In Spanish)

13. Skewes, M.A.; Stern, C.R. Tectonic trigger for the formation of late Miocene Cu-rich breccia pipes in the Andes of central Chile. Geology 1994, 22, 551-554. [CrossRef]

14. Kurtz, A.C.; Kay, S.M.; Charrier, R.; Farrar, E. Geochronology of Miocene plutons and exhumation history of the El Teniente region, Central Chile (34-35 S). Rev. Geol. Chile 1997, 16, 145-162.

15. Charrier, R.; Baeza, O.; Elgueta, S.; Flynn, J.J.; Gans, P.; Kay, S.M.; Muñoz, N.; Wyss, A.R.; Zurita, E. Evidence for Cenozoic extensional basin development and tectonic inversion south of the flat-slab segment, southern Central Andes, Chile (33-36 S.L.). J. S. Amer. Earth Sci. 2002, 15, 117-139. [CrossRef]

16. Giambiagi, L.B.; Ramos, V.A. Structural evolution of the Andes in a transitional zone between flat and normal subduction ( $33^{\circ} 30^{\prime}-33^{\circ} 45^{\prime}$ S), Argentina and Chile. J. S. Amer. Earth Sci. 2002, 15, 101-116. [CrossRef]

17. Nyström, J.; Vergara, M.; Morata, D.; Levi, B. Tertiary volcanism during extension in the Andean foothills of central Chile $\left(33^{\circ} 15^{\prime}-33^{\circ} 45^{\prime}\right.$ S). Geol. Soc. Amer. Bull. 2003, 115, 1523-1537. [CrossRef] 
18. Farías, M.; Charrier, R.; Carretier, S.; Martinod, J.; Fock, A.; Campbell, D.; Cáceres, J.; Comte, D. Late Miocene high and rapid surface uplift and its erosional response in the Ande of central Chile $\left(33^{\circ}-35^{\circ} \mathrm{S}\right)$. Tectonics 2008, 27, 1-22. [CrossRef]

19. Farías, M.; Comte, D.; Charrier, R.; Martinod, J.; Tassara, A.; Fock, A. Crustal-scale structural architecture of the central Chile Andes based on 3D seismic tomography, seismicity, and surface geology: Implications for mountain building in subduction zones. Tectonics 2010, 29, 1-22. [CrossRef]

20. Giambiagi, L.B.; Mescua, J.; Bechis, F.; Tassara, A.; Hoke, G. Thrust belts of the southern Central Andes: Along-strike variations in shortening, topography, crustal geometry, and denudation. Geol. Soc. Amer. Bull. 2012, 124, 1339-1351. [CrossRef]

21. Stern, C.R.; Skewes, M.A. Miocene to present magmatic evolution at the northern end of the Andean Southern Volcanic Zone, central Chile. Rev. Geol. Chile 1995, 22, 261-272.

22. Stern, C.R.; Floody, R.; Espiñeira, D. Pliocene olivine-hornblende-lamprophyre dikes from Quebrada de los Sapos, El Teniente, Central Chile (34 S): Implications for the subarc mantle. Andean Geol. 2011, 38, 1-22.

23. Stern, C.R.; Skewes, M.A.; Arévalo, A. Magmatic evolution of the giant El Teniente Cu-Mo deposit, Central Chile. J. Petrol. 2012, 52, 1591-1617. [CrossRef]

24. Muñoz, M.; Farías, M.; Charrier, R.; Fanning, C.M.; Polvé, M.; Deckart, K. Isotopic shifts in the Cenozoic Andean arc of central Chile: Records of an evolving basement throughout cordilleran arc mountain building. Geology 2013, 41, 931-934. [CrossRef]

25. Stern, C.R. Pliocene to present migration of the volcanic front, Andean Southern Volcanic Zone. Rev. Geol. Chile 1989, 16, 145-162.

26. Yáñez, G.; Ranero, C.; von Huene, R.; Díaz, J. Magnetic anomaly interpretation across the southern Central Andes $\left(32^{\circ}-33.5^{\circ} \mathrm{S}\right)$ : The role of the Juan Fernández ridge in the late Tertiary evolution of the margin. J. Geophys. Res. 2001, 106, 6325-6345.

27. Yáñez, G.; Cembrano, J.; Pardo, M.; Ranero, C.; Selles, D. The Challenger-Juan Fernández-Maipo major tectonic transition of the Nazca-Andean subduction system at 33-34 S: Geodynamic evidence and implications. J. S. Amer. Earth Sci. 2002, 15, 23-38. [CrossRef]

28. Muñoz, M.; Charrier, R.; Fanning, C.M.; Maksaev, V.; Deckart, K. Zircon trace element and O-Hf isotope analyses of mineralized intrusions from El Teniente ore deposit, Chilean Andes: Constraints on the source and magmatic evolution of porphyry Cu-Mo related magmas. J. Petrol. 2012, 53, 1091-1122. [CrossRef]

29. Lindgren, W.; Bastin, E.S. Geology of the Braden mine, Rancagua, Chile. Econ. Geol. 1922, 17, 75-99. [CrossRef]

30. Howell, F.H.; Molloy, S. Geology of the Braden orebody, Chile, South America. Econ. Geol. 1960, 70, 863-905. [CrossRef]

31. Camus, F. Geology of the El Teniente orebody with emphasis on wall-rock alteration. Econ. Geol. 1975, 70, 1341-1372. [CrossRef]

32. Cuadra, P. Geocronología K-Ar del yacimiento El Teniente y áreas adyacentes. Rev. Geol. Chile 1986, 27, 3-26. (In Spanish)

33. Skewes, M.A.; Arévalo, A.; Floody, R.; Zuñiga, P.; Stern, C.R. The giant El Teniente breccia deposit: Hypogene copper distribution and emplacement. In Global Exploration 2002: Integrated Methods of Discovery; Goldfarb, R.J., Nielson, R.L., Eds.; Society of Economic Geologists: Littleton, CO, USA, 2002; pp. 299-332.

34. Skewes, M.A.; Arévalo, A.; Floody, R.; Zuñiga, P.; Stern, C.R. The El Teniente megabreccia deposit. In Super Porphyry Copper and Gold Deposits: A Global Perspective; Porter, T.M., Ed.; PGC Publishing: Adelaide, Australia, 2005; Volume 1, pp. 83-114.

35. Maksaev, V.; Munizaga, F.; McWilliams, M.; Fanning, M.; Marther, R.; Ruiz, J.; Zentilli, M. Chronology for El Teniente, Chilean Andes, from U-Pb, ${ }^{40} \mathrm{Ar} /{ }^{39} \mathrm{Ar}$, Re-Os, and fission track dating: Implications for the formation of a supergiant porphyry Cu-Mo deposit. In Andean Metallogeny: New Discoveries, Concepts and Updates; Sillitoe, R.H., Perelló, J., Vidal, C.E., Eds.; Society of Economic Geologists: Littleton, CO, USA, 2004; pp. $15-54$.

36. Cannell, J.; Cooke, D.; Walshe, J.L.; Stein, H. Geology, mineralization, alteration, and structural evolution of El Teniente porphyry Cu-Mo deposit. Econ. Geol. 2005, 100, 979-1004. [CrossRef]

37. Vry, V.H.; Wilkinson, J.J.; Seguel, J.; Millán, J. Multistage intrusion brecciation and veining at El Teniente, Chile: Evolution of a nested porphyry system. Econ. Geol. 2010, 105, 119-153. [CrossRef] 
38. Skewes, M.A.; Stern, C.R. Genesis of the giant Late Miocene to Pliocene copper deposits of central Chile in the context of Andean magmatic and tectonic evolution. Internat. Geol. Rev. 1995, 37, 71-84. [CrossRef]

39. Stern, C.R.; Skewes, M.A. Origin of giant Miocene and Pliocene Cu-Mo deposits in Central Chile: Role of ridge subduction, decreased subduction angle, subduction erosion, crustal thickening and long-lived, batholiths-size, open system magma chambers. In Super Porphyry Copper and Gold Deposits: A Global Perspective; Porter, T.M., Ed.; PGC Publishing: Adelaide, Australia, 2005; Volume 1, pp. 65-82.

40. Warnaars, F.W.; Holmgren, C.; Barassi, S. Porphyry copper and Tourmaline breccias at Los Bronces-Río Blanco, Chile. Econ. Geol. 1985, 80, 1544-1565. [CrossRef]

41. Skewes, M.A.; Stern, C.R. Late Miocene mineralized breccias in the Andes of central Chile: Sr- and Nd-isotopic evidence for multiple magmatic sources. In Andean Copper Deposits; Camus, F., Sillitoe, R.H., Petersen, R., Eds.; Society of Economic Geologists: Littleton, CO, USA, 1996; pp. 119-130.

42. Skewes, M.A.; Holmgren, C.; Stern, C.R. The Donoso copper-rich, tourmaline-bearing breccia pipe in central Chile: Petrologic, fluid inclusion and stable isotope evidence for an origin from magmatic fluids. Mineral. Depos. 2003, 38, 2-21. [CrossRef]

43. Kusakabe, M.; Hori, M.; Nakagawa, S.; Matsuhisa, Y.; Ojeda, J.M.; Serrano, L.M. Oxygen and sulfur isotopic compositions of quartz, anhydrite and sulfide minerals from the El Teniente and Río Blanco porphyry copper deposits, Chile. Bull. Geol. Surv. Jpn. 1984, 35, 583-614.

44. Kusakabe, M.; Hori, M.; Matsuhisa, Y. Primary mineralization-alteration of the El Teniente and Rio Blanco porphyry copper deposits, Chile; stable isotope, fluid inclusion and $\mathrm{Mg}^{2+} / \mathrm{Fe}^{2+} / \mathrm{Fe}^{3+}$ ratios of hydrothermal fluids. In Stable Isotopes and Fluid Processes in Mineralization; Herbert, H.K., Ho, S.E., Eds.; University of Western Australia Press: Perth, Australia, 1990; pp. 244-259.

45. Puig, A. Geologic and metallogenic significance of the isotopic composition of lead in galenas of the Chilean Andes. Econ. Geol. 1988, 83, 843-858. [CrossRef]

46. Muñoz, M.; Fuentes, F.; Vergara, M.; Aguirre, L.; Nyström, J.O. Abanico East Formation: Petrology and geochemistry of volcanic rocks behind the Cenozoic arc front in the Andean Cordillera, central Chile (3350' S). Rev. Geol. Chile 2006, 33, 109-140. [CrossRef]

47. Montecinos, P.; Schárer, U.; Vergara, M.; Aguirre, L. Lithospheric origin of Oligocene-Miocene magmatism in Central Chile: $\mathrm{U}-\mathrm{Pb}$ ages and $\mathrm{Sr}-\mathrm{Pb}-\mathrm{Hf}$ isotope composition of minerals. J. Petrol. 2008, 49, 555-580. [CrossRef]

48. Godoy, E.; Yáñez, G.; Vera, E. Inversion of an Oligocene volcanic-tectonic basin and uplifting of its superimposed Miocene magmatic arc in the Chilean Central Andes: First seismic and gravity evidences. Tectonophys. 1999, 306, 217-236. [CrossRef]

49. Stern, C.R.; Funk, J.A.; Skewes, M.A.; Arévalo, A. Magmatic anhydrite in plutonic rocks at the El Teniente $\mathrm{Cu}-\mathrm{Mo}$ deposit, Chile, and the role of sulfur- and copper-rich magmas in its formation. Econ. Geol. 2007, 102, 1335-1344. [CrossRef]

50. Deckart, K.; Godoy, E.; Bertens, A.; Saeed, A.; Jeréz, D. Barren Miocene granitoids in the central Andean metallogenic belt, Chile: Geochemistry and Nd-Hf and U-Pb isotope systematics. Andean Geol. 2010, 37, 1-31. [CrossRef]

51. Blatter, D.K.; Carmichael, I.S.E. Hornblende peridotite xenoliths from central Mexico reveal the highly oxidized nature of subarc upper mantle. Geology 1998, 26, 1035-1038. [CrossRef]

52. Blatter, D.K.; Carmichael, I.S.E. Hydrous phase equilibria of a Mexican high-silica andesite: A candidate for mantle origin? Geochim. Cosmochim. Acta 2001, 65, 4043-4065. [CrossRef]

53. Moore, G.M.; Carmichael, I.S.E. The hydrous phase equilibra (to 3 kbar) of an andesite and basaltic andesite from Western Mexico: Constraints on water content and conditions of phenocrysts growth. Contrib. Mineral. Petrol. 1998, 130, 304-319. [CrossRef]

54. Carmichael, I.S.E. The andesite aqueduct: Perspectives in the evolution of intermediate magmas in west-central Mexico. Contrib. Mineral. Petrol. 2002, 143, 641-663. [CrossRef]

55. Barcley, J.; Carmichael, I.S.E. A Hornblende Basalt from Western Mexico: Water-saturated Phase Relations Constrain a Pressure-Temperature Window of Eruptibility. J. Petrol. 2004, 45, 485-506. [CrossRef]

56. Rudnick, R.; Gao, S. Composition of the continental crust. In The Crust; Rudnick, R.L., Holland, H.D., Turekian, K.K., Eds.; Elsevier-Pergamon: Oxford, UK, 2002; pp. 1-64.

57. McDonough, W.F.; Sun, S.S. The composition of the Earth. Chem. Geol. 1995, 120, 223-253. [CrossRef] 
58. Straub, S.M.; Gómez-Tuena, A.; Bindeman, I.N.; Bolge, L.L.; Brandl, P.A.; Espinasa-Perena, R.; Solari, L.; Stuart, F.M.; Vannucchi, P.; Zellmer, G.F. Crustal recycling by subduction erosion in the central Mexican Volcanic Belt. Geochim. Cosmochim. Acta 2015, 166, 29-52. [CrossRef]

59. Tera, F.; Brown, L.; Morris, J.; Sacks, I.S. Sediment incorporation in island-arc magmas: Inferences from ${ }^{10} \mathrm{Be}$. Geochim. Cosmochim. Acta 1986, 50, 535-550. [CrossRef]

60. Morris, J.D.; Leeman, W.P.; Tera, F. The subducted component in island arc lavas: Constraints from Be isotopes and B-Be systematics. Nature 1990, 344, 31-36. [CrossRef] [PubMed]

61. Morris, J.D.; Gosse, J.; Brachfeld, S.; Tera, F. Cosmogenic ${ }^{10} \mathrm{Be}$ and the solid earth: Studies in geomagnetism, subduction zone processes, and active tectonics. In Reviews in Mineralogy; Grew, E., Ed.; Mineralogical Society of America: Washington, DC, USA, 2002; pp. 207-270.

62. Tonarini, S.; Leeman, W.P.; Leat, P.T. Subduction erosion of forearc mantle wedge implicated in the genesis of the South Sandwich Island (SSI) arc: Evidence from boron isotope systematics. Earth Planet. Sci. Lett. 2011, 301, 275-284. [CrossRef]

63. Gómez-Tuena, A.; Cavazos-Tovar, J.G.; Parolari, M.; Straub, S.M.; Espinasa-Pereña, R. Geochronological and geochemical evidence of continental crust 'relamination' in the origin of intermediate arc magmas. Lithos 2018, 322, 52-66. [CrossRef]

64. Goss, A.R.; Kay, S.M. Steep REE patterns and enriched Pb isotopes in southern Central American arc magmas: Evidence for forearc subduction erosion? Geochem. Geophys. Geosyst. 2006, 7, 1-20. [CrossRef]

65. Freydier, C.; Ruiz, J.; Chesley, J.; Candless, T.; Munizaga, F. Re-Os isotope systematics of sulfides from felsic igneous rocks: Application to base metal porphyry mineralization in Chile. Geology 1997, 25, 775-778. [CrossRef]

66. Klemm, L.M.; Pettke, T.; Heinrich, C.L.; Campos, E. Hydrothermal evolution of the El Teniente deposit, Chile: Porphyry Cu-Mo ore deposition from low-salinity magmatic fluids. Econ. Geol. 2007, 102, 1021-1045. [CrossRef]

67. Hattori, K.H.; Keith, J.D. Contributions of mafia melt for porphyry deposits: Evidence from Pinatubo and Bingham. Mineral. Depos. 2001, 36, 799-806. [CrossRef]

68. Annen, C.; Blundy, J.D.; Sparks, R.S.J. The genesis of intermediate and silica magmas in deep crustal hot zones. J. Petrol. 2006, 47, 505-539. [CrossRef]

69. Cloos, M. Bubbling magma chambers, cupulas and porphyry copper deposits. Internat. Geol. Revs. 2001, 43, 285-311. [CrossRef]

70. Richards, J.P. Cumulative factors in the generation of giant calc-alkaline porphyry Cu deposits. In Super Porphyry Copper and Gold Deposits: A Global Perspective; Porter, T.M., Ed.; PGC Publishing: Adelaide, Australia, 2005; Volume 1, pp. 7-26.

71. Garrido, I.; Cembrano, J.; Siña, A.; Stedman, P.; Yáñez, G.A. High magma oxidation state and bulk crustal shortening: Key factors in the genesis of Andean porphyry copper deposits, central Chile (31-34 $\left.{ }^{\circ} \mathrm{S}\right)$. Rev. Geol. Chile 2002, 29, 43-54. [CrossRef]

(C) 2019 by the authors. Licensee MDPI, Basel, Switzerland. This article is an open access article distributed under the terms and conditions of the Creative Commons Attribution (CC BY) license (http://creativecommons.org/licenses/by/4.0/). 